\title{
Mercury oxidation from bromine chemistry in the free troposphere over the southeastern US
}

\author{
Sean Coburn ${ }^{1,2}$, Barbara Dix ${ }^{1}$, Eric Edgerton ${ }^{3}$, Christopher D. Holmes ${ }^{4}$, Douglas Kinnison ${ }^{5}$, Qing Liang ${ }^{6}$, \\ Arnout ter Schure $^{7}$, Siyuan Wang ${ }^{1,2, a}$, and Rainer Volkamer ${ }^{1,2}$ \\ ${ }^{1}$ Department of Chemistry and Biochemistry, University of Colorado Boulder, Boulder, CO, USA \\ ${ }^{2}$ Cooperative Institute for Research in Environmental Sciences (CIRES), Boulder, CO, USA \\ ${ }^{3}$ Atmospheric Research and Analysis (ARA) Inc., Plano, TX, USA \\ ${ }^{4}$ Department of Earth, Ocean and Atmospheric Science, Florida State University, Tallahassee, FL, USA \\ ${ }^{5}$ National Center for Atmospheric Research (NCAR), Boulder, CO, USA \\ ${ }^{6}$ NASA Goddard Space Flight Center, Atmospheric Chemistry and Dynamics Branch, Greenbelt, MD 20771, USA \\ ${ }^{7}$ Electric Power Research Institute (EPRI), Palo Alto, CA, USA \\ ${ }^{a}$ now at: Department of Chemistry, University of Michigan, Ann Arbor, MI, USA
}

Correspondence to: Rainer Volkamer (rainer.volkamer@colorado.edu)

Received: 18 August 2015 - Published in Atmos. Chem. Phys. Discuss.: 21 October 2015

Revised: 28 February 2016 - Accepted: 4 March 2016 - Published: 21 March 2016

\begin{abstract}
The elevated deposition of atmospheric mercury over the southeastern United States is currently not well understood. Here we measure partial columns and vertical profiles of bromine monoxide ( $\mathrm{BrO}$ ) radicals, a key component of mercury oxidation chemistry, to better understand the processes and altitudes at which mercury is being oxidized in the atmosphere. We use data from a ground-based MAX-DOAS instrument located at a coastal site $\sim 1 \mathrm{~km}$ from the Gulf of Mexico in Gulf Breeze, FL, where we had previously detected tropospheric $\mathrm{BrO}$ (Coburn et al., 2011). Our profile retrieval assimilates information about stratospheric $\mathrm{BrO}$ from the WACCM chemical transport model (CTM), and uses only measurements at moderately low solar zenith angles (SZAs) to estimate the BrO slant column density contained in the reference spectrum $\left(\mathrm{SCD}_{\mathrm{Ref}}\right)$. The approach has 2.6 degrees of freedom, and avoids spectroscopic complications that arise at high SZA; knowledge about $\mathrm{SCD}_{\mathrm{Ref}}$ further helps to maximize sensitivity in the free troposphere (FT). A cloud-free case study day with low aerosol load (9 April 2010) provided optimal conditions for distinguishing marine boundary layer (MBL: 0-1 km) and free-tropospheric (FT: $1-15 \mathrm{~km}$ ) BrO from the ground. The average daytime tropospheric $\mathrm{BrO}$ vertical column density (VCD) of $\sim 2.3 \times 10^{13} \mathrm{molec} \mathrm{cm}^{-2}\left(\mathrm{SZA}<70^{\circ}\right)$ is consistent with our earlier reports on other days. The verti-
\end{abstract}

cal profile locates essentially all tropospheric $\mathrm{BrO}$ above $4 \mathrm{~km}$, and shows no evidence for $\mathrm{BrO}$ inside the $\mathrm{MBL}$ (detection limit $<0.5 \mathrm{pptv}$ ). BrO increases to $\sim 3.5 \mathrm{pptv}$ at $10-15 \mathrm{~km}$ altitude, consistent with recent aircraft observations. Our case study day is consistent with recent aircraft studies, in that the oxidation of gaseous elemental mercury (GEM) by bromine radicals to form gaseous oxidized mercury (GOM) is the dominant pathway for GEM oxidation throughout the troposphere above Gulf Breeze. The column integral oxidation rates are about $3.6 \times 10^{5}$ molec cm $^{-2} \mathrm{~s}^{-1}$ for bromine, while the contribution from ozone $\left(\mathrm{O}_{3}\right)$ is $0.8 \times 10^{5}$ molec cm $\mathrm{cm}^{-2} \mathrm{~s}^{-1}$. Chlorine-induced oxidation is estimated to add $<5 \%$ to these mercury oxidation rates. The GOM formation rate is sensitive to recently proposed atmospheric scavenging reactions of the $\mathrm{HgBr}$ adduct by nitrogen dioxide $\left(\mathrm{NO}_{2}\right)$, and to a lesser extent also $\mathrm{HO}_{2}$ radicals. Using a 3-D CTM, we find that surface GOM variations are also typical of other days, and are mainly derived from the FT. Bromine chemistry is active in the FT over Gulf Breeze, where it forms water-soluble GOM that is subsequently available for wet scavenging by thunderstorms or transport to the boundary layer. 


\section{Introduction}

Measurements of tropospheric halogen species are an area of increasing research interest due to the ability of halogens to destroy tropospheric ozone $\left(\mathrm{O}_{3}\right)$ (Tossell, 2003; Holmes et al., 2009; Hynes et al., 2009), oxidize atmospheric mercury (Holmes et al., 2009; Hynes et al., 2009), and modify oxidative capacity (Parella et al., 2012). Most assessments of the impacts of halogen chemistry are based on measurements of halogen oxides (bromine monoxide, $\mathrm{BrO}$, and iodine monoxide, IO), since these radicals are typically found at higher concentrations throughout the troposphere than the corresponding halogen atom radicals. Many of these studies take place in the planetary boundary layer (PBL), given that this region of the atmosphere is easily accessible from measurements located at the surface, and is also the most directly impacted by anthropogenic activities. However, halogen chemistry in the free troposphere (FT), albeit more challenging to measure, has the potential to affect an even larger air volume and mass. In particular, the colder temperatures of the free troposphere accelerate the bromine oxidation of gaseous elemental mercury (GEM) (Donohoue et al., 2006). Satellite-borne measurements represent a powerful resource for assessing global distributions and tropospheric vertical column densities (VCDs) of BrO (GOME - Van Roozendael et al., 2002; GOME-2 - Theys et al., 2011; Sihler et al., 2012). However, satellite retrievals rely on assumptions made about the vertical distribution of $\mathrm{BrO}$, and uncertainties in these assumptions can lead to over- or underpredictions in the derived tropospheric VCD. The most direct method for measuring trace gas vertical distributions is through the use of aircraft (Prados Ramon et al., 2011; Volkamer et al., 2015) or balloons (Fitzenberger et al., 2000; Pundt et al., 2002; Dorf et al., 2006). However, this type of measurement is costly and potentially impractical if the goal is to establish long term trends in the FT. Ground-based measurements are typically more straightforward to deploy and maintain for extended periods of time, but optimizing ground-based capabilities to observe the FT remains an area of active research (Schofield et al., 2006; Theys et al., 2007; Hendrick et al., 2007; Coburn et al., 2011). Specifically, ground-based multi-axis differential optical absorption spectroscopy (MAX-DOAS) measurements are uniquely suited for this type of study since this technique also assesses vertical distributions, and derived VCDs can be directly compared with models and satellites. Additionally, the DOAS retrieval allows for the detection of not only $\mathrm{BrO}$, but also other trace gases that have significant impacts on the chemical cycling of bromine species in the atmosphere, such as $\mathrm{NO}_{2}$ and some volatile organic compounds (VOCs). However, measurements of $\mathrm{FT} \mathrm{BrO}$ from ground-based MAX-DOAS are not straightforward for several reasons: (1) stratospheric $\mathrm{BrO}$ represents a large portion of the measured signal and creates a background that has to be accounted for when attempting to assess the FT, (2) ozone absorption structures are strongly present in the same wavelength region as $\mathrm{BrO}$ and can create interferences due to stratospheric ozone absorption, in particular at high solar zenith angles (SZAs) (Aliwell et al., 2002; Van Roozendael et al., 2002); and (3) the sensitivity of this technique peaks at the instrument altitude and decreases with increasing altitude. Recent advances with testing stratospheric $\mathrm{BrO}$ profiles in atmospheric models (Liang et al., 2014) provide opportunities to properly account for point 1 by assimilating information from atmospheric models. Furthermore, retrievals that avoid SZAs larger than $70^{\circ}$ do not suffer from 2, and certain measurement geometries retain information about the FT. Figure S1 (Supplement) depicts the box air mass factors (bAMFs), which represent the sensitivity of the slant column density (SCD) measurement geometry to $\mathrm{BrO}$ concentrations at different altitudes, for two pointing directions (or elevation angles, $\mathrm{EA}=25$ and $90^{\circ}$ upwards) at several SZA; at $\mathrm{SZA}<70^{\circ}$ the sensitivity of these EAs peaks between 2 and $15 \mathrm{~km}$. A more comprehensive view of the bAMFs for different EAs over a wider SZA range is shown in Fig. S2.

Van Roozendael et al. (2002) compared ground-based and balloon-borne measurements to VCDs of $\mathrm{BrO}$ from the space-borne Global Ozone Monitoring Experiment (GOME) and found all platforms were consistent with a rather widespread tropospheric $\mathrm{BrO}$ VCD of 1$3 \times 10^{13}$ molec $\mathrm{cm}^{-2}$ once appropriate radiative transfer effects were taken into consideration. Salawitch et al. (2005) and Theys et al. (2011) also report satellite derived tropospheric BrO VCDs (GOME and GOME-2, respectively) for the midlatitudes of $2 \times 10^{13}$ and $1-3 \times 10^{13} \mathrm{molec} \mathrm{cm}^{-2}$, respectively. Ground-based measurements (Theys et al., 2007; Coburn et al., 2011) in the midlatitudes have reported BrO VCDs of $1-2 \times 10^{13}$ molec $\mathrm{cm}^{-2}$ that are comparable to the findings from satellites. Volkamer et al. (2015) recently reported $1.6 \times 10^{13}$ molec cm $^{-2} \mathrm{BrO}$ VCD in the tropics measured by limb observations from aircraft. All of these studies point to the widespread presence of $\mathrm{BrO}$ in the FT, corresponding to a VCD of $1-3 \times 10^{13} \mathrm{molec} \mathrm{cm}^{-2}$. Based on these reports, tropospheric $\mathrm{BrO}$ could account for $20-30 \%$ of a total BrO VCD $\sim 5-6 \times 10^{13} \mathrm{molec} \mathrm{cm}^{-2}$ as seen from satellite (Van Roozendael et al., 2002; Theys et al., 2011), and significantly impacts the lifetime of tropospheric $\mathrm{O}_{3}$ and atmospheric GEM (Wang et al., 2015).

\section{Atmospheric Hg in the southeastern US}

Mercury in the atmosphere exists in three forms: gaseous elemental mercury $\left(\mathrm{Hg}^{0}, \mathrm{GEM}\right)$, gaseous oxidized mercury in the form of either $\mathrm{Hg}^{2+}$ or $\mathrm{Hg}^{1+}(\mathrm{GOM})$, and particle-bound mercury (PBM). Understanding the processes that cycle mercury between its various forms (GEM $\leftrightarrow \mathrm{GOM} \leftrightarrow \mathrm{PBM}$ ) is of great importance, because this speciation controls the deposition of mercury to the environment -i.e., GOM and PBM are more readily removed from the atmosphere via wet and dry deposition than GEM (Lindberg and Stratton, 1998; Bullock, 2000). Once deposited, biological processes can methy- 


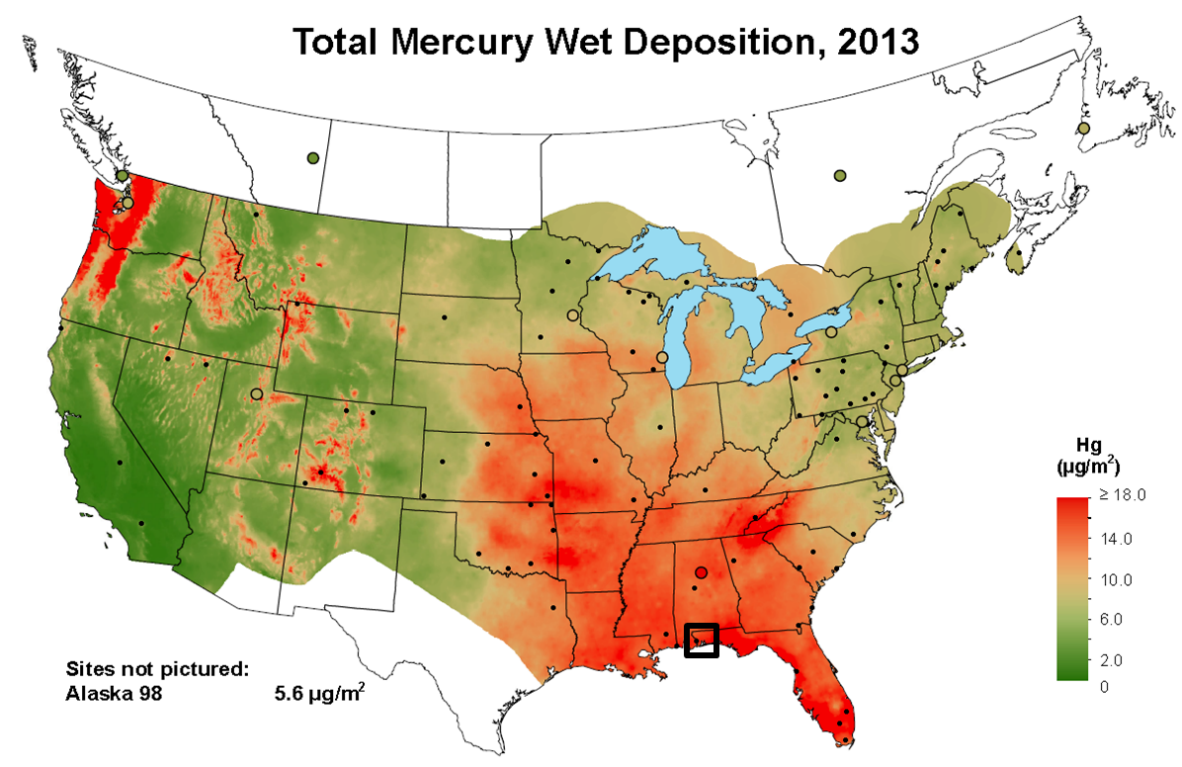

National Atmospheric Deposition Program/Mercury Deposition Network http://nadp.isws.illinois.edu

Figure 1. Total mercury wet deposition in the US for 2013. The highest levels of Hg deposition are observed in the southeastern US, where no local and regional sources are located immediately upwind. The black square indicates the measurement location.

late $\mathrm{Hg}^{2+}$ to form the neurotoxin methyl mercury, which bioaccumulates in fish. Enhancement factors for methyl mercury of up to $10^{6}$ relative to water have been measured in predatory fish tissues (Schroeder and Munthe, 1998; Selin et al., 2010).

A better understanding of the processes controlling atmospheric mercury oxidation, and therewith removal, is particularly relevant for regions that experience high levels of mercury deposition, such as the southeastern United States (SE US). Figure 1 shows a map of the total mercury wet deposition in the US from 2013 (http://nadp.sws.uiuc.edu/ maplib/pdf/mdn/hg_dep_2013.pdf). The high deposition levels experienced in the SE US cannot be explained by regional anthropogenic sources of mercury alone, which are mainly located within the Ohio River valley, where the prevailing winds carry emissions northeast. Additionally, several modeling studies (Zhang et al., 2012; Nair et al., 2013) have shown that meteorological patterns above the SE US greatly influence the wet deposition of mercury and that these processes are linked with deep convective activity. This indicates that a regional emission-deposition pattern is most likely not the major source-receptor relationship for mercury entering the environment over Florida, in the SE US, meaning that other possibilities, such as enhanced atmospheric oxidation followed by deposition, need to be explored.

\section{Experimental section}

\subsection{Atmospheric conditions}

The case study during 9 April 2010 provided optimal conditions for assessing the ability of a ground-based MAXDOAS instrument to measure FT trace gases (see Sect. S1 in the Supplement for a brief overview of instrumentation and measurement site). Figure 2 shows a time series of trace gas differential slant column densities (dSCDs) of $\mathrm{BrO}, \mathrm{IO}$, $\mathrm{NO}_{2}$, and $\mathrm{O}_{4}$ for the week surrounding the case study day, with 9 April highlighted by the blue box. The IO measurements are assimilated and used in the modeling portion of this study (Sect. 3.4), while the $\mathrm{NO}_{2}$ measurements give an indication on the amount of influence from anthropogenic activities in the lowest layers of the BL. This day provides an excellent case study for two reasons: (1) consistent shape of the $\mathrm{O}_{4}$ dSCDs across elevation angles, as well as the clear splitting between the values, is a good indicator for a cloudfree day and (2) the relatively high $\mathrm{O}_{4} \mathrm{dSCD}$ values (compared with other days) indicate a low aerosol load, enabling the instrument to realize longer light paths (increased sensitivity due to fewer extinction events), and an unobstructed view of the FT. An inspection of webcam pictures for the instrument site proved the day to be free of visual clouds, and a precursory look at the aerosol load confirmed the low values. Figure 2 also contains in situ $\mathrm{O}_{3}$ measurements (from both the US EPA site and a nearby Mercury Deposition Network (MDN) site), oxidized mercury measurements (see below), as well as wind direction measurements from a 


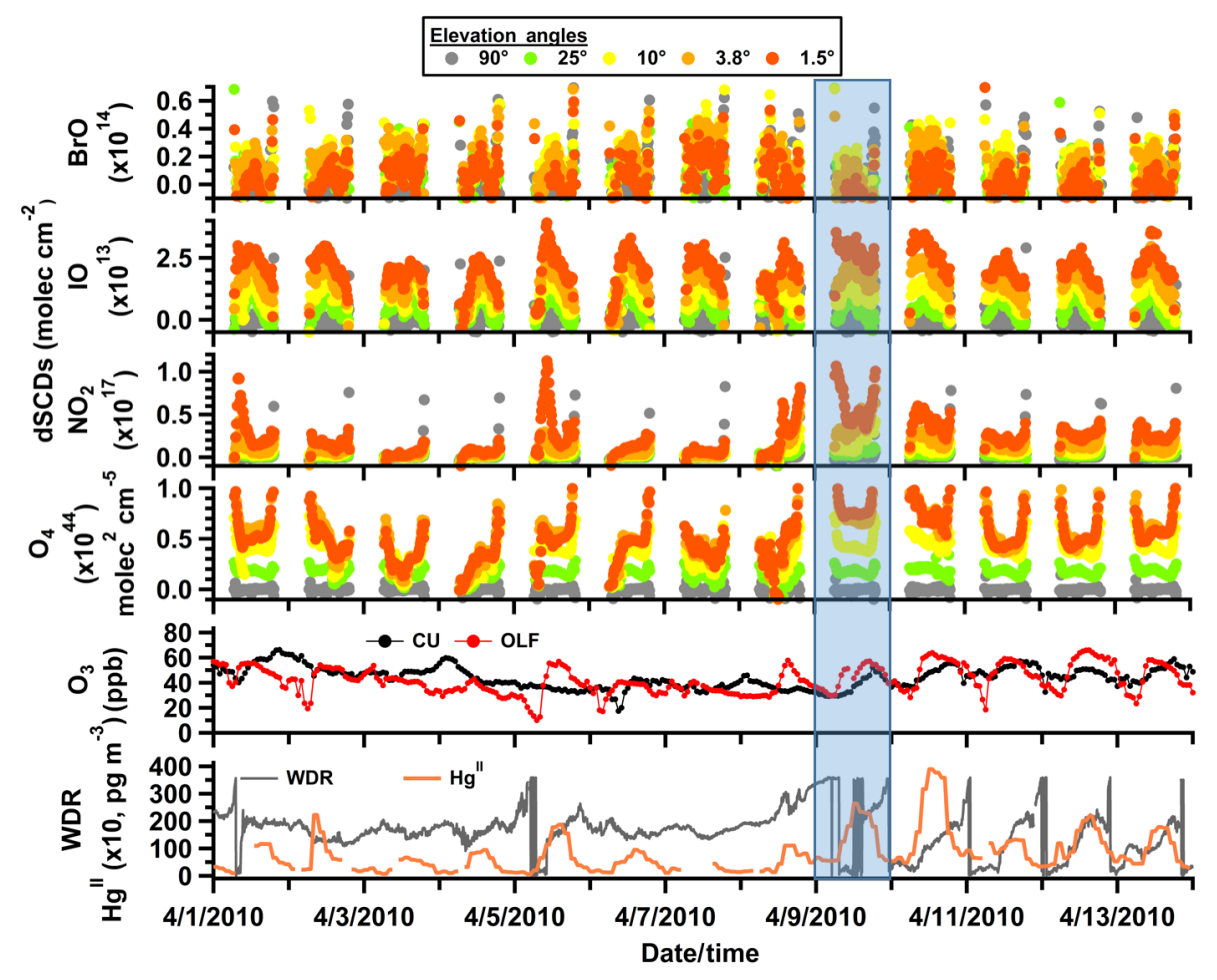

Figure 2. Overview of the MAX-DOAS measurements for the week surrounding the case study day (9 April, highlighted with blue box). Also included are $\mathrm{O}_{3}$ measurements from a monitor collocated with the MAX-DOAS instrument (label "CU", black trace) and a monitor located at a Mercury Deposition Network (MDN) site $30 \mathrm{~km}$ northwest of the EPA site (label "OLF", red trace), and wind direction measurements (grey trace) from a site near the EPA facility along with $\mathrm{Hg}^{\mathrm{II}}$ measurements from the MDN site (scaled by a factor of 10 , orange trace).

WeatherFlow, Inc. monitoring station located in Gulf Breeze, FL near the US EPA site.

Oxidized mercury measurements $\left(\mathrm{Hg}^{\mathrm{II}}=\mathrm{GOM}+\mathrm{PBM}\right)$ at the Pensacola MDN site during study period (see Edgerton et al., 2006, for a detailed description of the site and instrumentation) are also shown in the bottom panel of Fig. 2 (also Fig. 9, Sect. 3.4). On 9 April, $\mathrm{Hg}^{\mathrm{II}}$ concentrations at the MDN site were rising from near zero on 8 April (due to rain) to peak values of $15-40 \mathrm{pg} \mathrm{m}^{-3}$ on the following days, which is above average for the season. In prior years, average daily peak concentrations at this site in spring were $15 \mathrm{pg} \mathrm{m}^{-3}$, which is higher than during any other season (Weiss-Penzias et al., 2011; Nair et al., 2012). Observed GEM concentrations are persistently around $1.4 \mathrm{ng} \mathrm{m}^{-3}$ throughout early April, as expected for this season, and therefore not shown. It should be noted that recent studies have found that measurements of $\mathrm{Hg}^{\mathrm{II}}$ using $\mathrm{KCl}$ denuders can be influenced by atmospheric conditions and other trace gases (McClure et al., 2014) and these external factors can lead to an underestimation of $\mathrm{Hg}^{\mathrm{II}}$.

\subsection{External model overview}

The Whole Atmosphere Community Climate Model version 4 (WACCM4) (Garcia et al., 2007; Marsh et al., 2013) has been extensively evaluated for its representation of the stratosphere, including stratospheric $\mathrm{BrO}$ (Eyring et al., 2010). The model does not represent tropospheric bromine sources from very short lived species (VSLSs, bromocarbons) and using this model in this study is an active choice to ensure that a priori information about tropospheric $\mathrm{BrO}$ represents a lower limit (see Sect. 2.4.1). However, $\mathrm{CHBr}_{3}$ and $\mathrm{CH}_{2} \mathrm{Br}_{2}$ concentrations are fixed at the cold point and add about 5-6 pptv stratospheric $\mathrm{Br}_{y}$ (stratospheric $\mathrm{Br}_{y}$ loading is $21-22 \mathrm{pptv}$ ). In this work, WACCM is run with specified (external) meteorological fields. This is achieved by relaxing the horizontal winds and temperatures to reanalysis fields. The reanalysis fields used are taken from the NASA Global Modeling and Assimilation Office (GMAO) Modern-Era Retrospective Analysis for Research and Applications (MERRA) (Rienecker et al., 2011). The horizontal resolution is $1.9^{\circ} \times 2.5^{\circ}$ (latitude $\times$ longitude), with 88 vertical levels from the surface to the lower thermosphere $(-140 \mathrm{~km})$. Other WACCM model outputs used are $\mathrm{HCHO}$, temperature, and pressure vertical profiles. Timesynchronized $\mathrm{BrO}$ vertical profiles from WACCM are used as a priori inputs to the inversion (tropospheric VCDs $\sim 1 \times 10^{13}$ molec $\mathrm{cm}^{-2}$ ), while HCHO profiles are used as input for the box model utilized in this study (see Sect. S4). Temperature and pressure profiles were used to construct a molecular density profile in order to convert from concen- 
tration (output units of the inversion) to volume mixing ratios (VMRs). Model data were generated specifically for this case study in order to best represent that atmospheric composition at the time of the measurements.

The GEOS-Chem global chemical transport model (CTM) is used to provide a regional and seasonal context for the DOAS observations and their relevance to mercury chemistry. GEOS-Chem (v9-02, http:www.geos-chem.org) is driven by assimilated meteorology from the NASA Goddard Earth Observing System (GEOS-5). Simulations here have $2^{\circ} \times 2.5^{\circ}$ horizontal resolution at 47 vertical layers for bromine and all species except mercury, which have $4^{\circ} \times 5^{\circ}$ horizontal resolution. The bromine chemical mechanism, described by Parrella et al. (2012), includes marine bromocarbon emissions from Liang et al. (2010) and debromination of sea salt aerosols (Sander et al., 2003; Yang et al., 2005). Tropospheric bromine concentrations from GEOS-Chem are merged with stratospheric bromine from GEOS-CCM (Liang et al., 2010) to produce a complete atmospheric column (tropospheric VCD of $1.5 \times 10^{13}$ molec $\mathrm{cm}^{-2}$ ). The GEOSChem $\mathrm{BrO}$ vertical profile is also used as input to the box model in order to assess sensitivity to differences between measured and modeled $\mathrm{BrO}$ vertical distributions on mercury oxidation; GEOS-Chem $\mathrm{O}_{3}$ and $\mathrm{NO}_{2}$ profiles are also used as input to the box model. Additionally, the GEOS-CCM profile is utilized as an a priori during the inversion of the MAXDOAS measurements due to its representation of the stratosphere while excluding most bromine chemistry in the troposphere (lower limit of bromine in the FT, tropospheric VCD of $3.5 \times 10^{12}$ molec $\mathrm{cm}^{-2}$ ). The mercury simulation is configured as described by Zhang et al. (2012), which includes GEM and two $\mathrm{Hg}^{\mathrm{II}}$ species: GOM and PBM. Anthropogenic mercury emissions are from the US EPA National Emission Inventory (NEI) 2005 and National Pollutant Release Inventory (NPRI) 2005 inventories over North America (Zhang et al., 2012), which are adjusted to account for $\mathrm{Hg}^{\mathrm{II}}$ reduction in power plant plumes (Landis et al., 2014), and elsewhere from the Global Emission Inventory Activity (GEIA) (Streets et al., 2009; Corbitt et al., 2011). Emissions and cycling from oceans and the biosphere are also included (Selin et al., 2008; Soerensen et al., 2010). Atmospheric GEM is oxidized by bromine (Holmes et al., 2010) using updated kinetic rate coefficients from Goodsite et al. (2012) and bromine concentrations from GEOS-Chem. $\mathrm{Hg}^{\mathrm{II}}$ partitions between GOM and PBM (Rutter and Schauer, 2007; Amos et al., 2012), which are both quickly scavenged by precipitation or dry deposited but also susceptible to reduction in cloud water. The bromine and mercury simulations are both spun up for at least 1 year. The model is then sampled hourly during April 2010 over Pensacola.

\subsection{DOAS BrO retrieval}

Following is a brief description of the parameters and settings used for the DOAS analysis of BrO for this study. A series of sensitivity studies on the BrO retrieval determined the optimal wavelength window for the analysis in this study to be 338-359 $\mathrm{nm}$ and include a fifth order polynomial. Sensitivity studies, which varied the fit window, polynomial order, and intensity offset, indicate that the chosen fit settings estimate $\mathrm{BrO}$ dSCDs conservatively, as is discussed in more detail in Sect. S2. The reference cross sections used in the DOAS retrieval (WinDOAS software; Fayt and van Roozendael, 2001) were $\mathrm{O}_{3}$ (at 223 and $243 \mathrm{~K}$; Bogumil et al., 2003), $\mathrm{NO}_{2}$ (at 220 and $297 \mathrm{~K}$; Vandaele et al., 1998), O 4 (at $293 \mathrm{~K}$; Thalman and Volkamer, 2013), HCHO (Meller and Moortgat, 2000), BrO (Wilmouth et al., 1999), and a Ring spectrum (Chance and Spurr, 1997) calculated using the software DOASIS (Kraus, 2006) at $250 \mathrm{~K}$ for the reference used in the analysis. Additionally, a constant intensity offset was included in the fit, but limited to a range $\left( \pm 3 \times 10^{-3}\right)$ determined by an estimation of the upper limit for the correction of spectrometer stray light. Details of the retrieval for other trace gases can be found in Table 1 along with an overview of the $\mathrm{BrO}$ retrieval settings listed here. A single zenith reference from a low SZA of the case study day was used to analyze all spectra (referred to as a fixed reference analysis). This spectrum was taken at $\sim$ 18:01 UTC on 9 April 2010 $\left(\sim 23^{\circ} \mathrm{SZA}\right)$.

\subsection{Inversion method}

The retrieval of the BrO VCDs and vertical profiles for this study is a three-step process: (1) aerosol profiles are determined based on DOAS measurements of $\mathrm{O}_{4}$ (see Sect. S3), (2) derived aerosol profiles are used in a radiative transfer model (RTM) to calculate weighting functions for BrO; and (3) weighing functions are used in an optimal estimation inversion of the DOAS dSCDs to derive VCDs and vertical profiles (Sect. 2.4.1). Additionally, a method is presented here for determining the residual amount of $\mathrm{BrO}$ contained in the reference spectrum $\left(\mathrm{SCD}_{\mathrm{Ref}}\right.$, Sect. 2.4.2). The relationship between $\mathrm{SCD}_{\text {Ref }}$ and the measured dSCDs is shown as Eq. (1).

$\mathrm{SCD}=\mathrm{dSCD}+\mathrm{SCD}_{\mathrm{Ref}}$

Both dSCDs and SCDs were used as input to the inversion, and sensitivity tests are presented to assess the impact of the $\mathrm{SCD}_{\mathrm{Ref}}$ value on the derived vertical profiles and VCDs.

\subsubsection{Trace gas inversion}

Weighting functions calculated at $350 \mathrm{~nm}$ (for $\mathrm{BrO}$ ) are used in an optimal estimation (OE) inversion (Rodgers, 2000) to determine the trace gas vertical profiles from the MAXDOAS dSCD measurements, as given by Eq. (2).

$x_{\mathrm{r}}=x_{\mathrm{a}}+\mathbf{A}\left(x_{\mathrm{t}}-x_{\mathrm{a}}\right)$

Here $x_{\mathrm{r}}$ represents the retrieved profile, $x_{\mathrm{a}}$ is the a priori profile assumption, $\mathbf{A}$ is the averaging kernel matrix (AVK), and 
Table 1. Overview of DOAS settings.

\begin{tabular}{llcccc}
\hline $\begin{array}{l}\text { Cross section, } \\
\text { parameter }\end{array}$ & Reference & $\begin{array}{c}\text { BrO window } \\
(338-359 \mathrm{~nm})\end{array}$ & $\begin{array}{c}\text { IO window } \\
(415-438 \mathrm{~nm})\end{array}$ & $\begin{array}{c}\mathrm{NO}_{2} \text { window } \\
(434-460 \mathrm{~nm})\end{array}$ & $\begin{array}{c}\mathrm{O}_{4} \text { window } \\
(437-486 \mathrm{~nm})\end{array}$ \\
\hline $\begin{array}{l}\text { Polynomial order } \\
\mathrm{O}_{3} T=223 \mathrm{~K}\end{array}$ & Bogumil et al. (2003) & 5 & 5 & 3 & 5 \\
$\mathrm{O}_{3} T=243 \mathrm{~K}$ & Bogumil et al. (2003) & $\mathrm{X}$ & $\mathrm{X}$ & $\mathrm{X}$ & $\mathrm{X}$ \\
$\mathrm{NO}_{2} T=220 \mathrm{~K}$ & Vandaele et al. (1998) & $\mathrm{X}$ & $\mathrm{X}$ & $\mathrm{X}$ & $\mathrm{X}$ \\
$\mathrm{NO}_{2} T=297 \mathrm{~K}$ & Vandaele et al. (1998) & $\mathrm{X}$ & $\mathrm{X}$ & $\mathrm{X}$ & $\mathrm{X}$ \\
$\mathrm{O}_{4} T=293 \mathrm{~K}$ & Thalman and Volkamer (2013) & $\mathrm{X}$ & & $\mathrm{X}$ \\
$\mathrm{BrO}$ & Wilmouth et al. (1999) & $\mathrm{X}$ & & $\mathrm{X}$ \\
$\mathrm{HCHO}$ & Meller and Moortgat (2000) & $\mathrm{X}$ & & $\mathrm{X}$ & \\
$\mathrm{IO}$ & Spietz et al. (2005) & & & $\mathrm{X}$ \\
$\mathrm{CHOCHO}$ & Volkamer et al. (2005) & & & $\mathrm{X}$ \\
$\mathrm{H} \mathrm{O}$ & Rothman et al. (2005) & & & $\mathrm{X}$ \\
\hline
\end{tabular}

$x_{\mathrm{t}}$ is the true atmospheric state (represented by the MAXDOAS dSCD or SCD measurements here). The AVK gives an indication of where the information in $x_{\mathrm{r}}$ is coming from, i.e., information from $x_{\mathrm{t}}$ (measurements) vs. $x_{\mathrm{a}}$ (a priori assumption). The trace of this matrix gives the degrees of freedom (DoFs) of the retrieval and indicates how many independent pieces of information are contained in the retrieval (see Sect. 3.1).

One important aspect in this study is the choice of the altitude grid used for both the radiative transfer calculations and the inversion. We used a grid of varying layer thickness: $0.5 \mathrm{~km}$ from 0 to $2 \mathrm{~km}$, a single $3 \mathrm{~km}$ layer from 2 to $5 \mathrm{~km}$, and $5 \mathrm{~km}$ layer thickness from 5 to $50 \mathrm{~km}$. This grid is chosen to effectively combine the information from multiple altitudes into a single grid point to ensure reasonable peaks in the averaging kernels at increasing altitude, where the MAXDOAS measurements have limited vertical resolution.

For the $\mathrm{BrO}$ inversion, four different a priori profiles are used in order to assess the robustness of the inversion (see Fig. 5, Sect. 3.2, which shows three of the a priori profiles along with their corresponding a posteriori results). Two of the a priori profiles are based on WACCM model output, the third used data from the CU Airborne MAX-DOAS (AMAXDOAS) instrument collected during the Tropical Ocean tRoposphere Exchange of Reactive halogen species and Oxygenated VOC (TORERO) 2012 field campaign (Volkamer et al., 2015), and the fourth is a mean profile from GEOS-CCM. The a priori profiles from WACCM are (1) direct model output for the time of each MAX-DOAS scan throughout the day (i.e., different a priori profile for each MAX-DOAS scan) and (2) the profiles from (1) increased by $40 \%$ (in VMR space). The a priori profile for the TORERO case is derived from data collected during research flight 12 (RF12; Volkamer et al., 2015), which also closely represents the tropical average BrO profile (see Fig. 2 in Wang et al., 2015). The GEOS-CCM profile is a daytime zonal mean at $30^{\circ} \mathrm{N}$. The TORERO and GEOS-CCM profiles are used to invert each MAX-DOAS scan, i.e., the same profile is used for each scan inversion. This is in contrast to the WACCM a priori profiles, which change throughout the day, due to the availability of time-resolved output. For reference, diurnal variations in the WACCM model output for $\mathrm{BrO}$ vertical distributions are shown in Fig. S3a, while Fig. S3b shows the corresponding tropospheric and total VCDs from these profiles. The a priori profile error used as input to the $\mathrm{OE}$ is constructed based on upper limit values (in units of VMR) expected throughout the troposphere; this is set at $1 \mathrm{pptv}$ for altitudes $0-2 \mathrm{~km}, 3 \mathrm{pptv}$ for $2-5 \mathrm{~km}$, and $4 \mathrm{pptv}$ for $5-20 \mathrm{~km}$ (except for the GEOS$\mathrm{CCM}$ case where this altitude range is set to $6 \mathrm{pptv}$ to account for the extremely low values found in the lower FT of the a priori). The a priori error is constrained to $40 \%$ for the stratospheric portion of the profile $(20-50 \mathrm{~km})$, based on the assumption that the WACCM and GEOS-CCM profiles in this region of the atmosphere accurately represent the true atmospheric state, but allowing for sufficient room to reflect contributions of very short-lived organo halogen species (VSLS) to stratospheric $\mathrm{BrO}$ (Liang et al., 2014).

A similar method is also used to derive IO profiles (used as input to the modeling in Sect. 3.4). The IO inversion uses two a priori profiles: (1) a moderate IO VMR in the BL $(0.2-0.5 \mathrm{pptv})$ and decreasing to very low levels $(<0.1 \mathrm{pptv})$ throughout the rest of the troposphere and (2) a profile from recently reported AMAX-DOAS measurements (Dix et al., 2013; Volkamer et al., 2015). A summary of the a priori profiles, example a posteriori profiles, the average (for the case study) profile, and the diurnal variation in the VCD for IO is found in Fig. S4.

\subsubsection{Determination of $\mathrm{SCD}_{\text {Ref }}$}

The $\mathrm{BrO}$ profile at the recording time of the fixed reference spectrum is included in the analysis by estimating the reference $\mathrm{SCD}\left(\mathrm{SCD}_{\mathrm{Ref}}\right)$ for $\mathrm{BrO}$, which is then added to the dSCDs at off-axis EAs according to Eq. (1). Initial sensitivity studies revealed that some MAX-DOAS scans from the case study day are better suited for producing consistent values for 

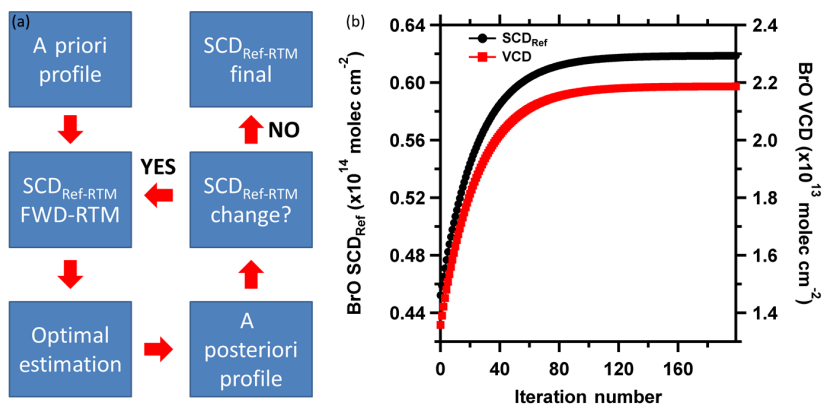

Figure 3. Conceptual sketch of the $S C D_{\text {Ref }}$ retrieval (a) and resulting $S_{C D}$ Ref values (black trace, $\mathbf{b}$ ). The sensitivity of the a posteriori BrO VCD (red trace) to $\mathrm{SCD}_{\text {Ref }}$ is also shown (b).

$\mathrm{SCD}_{\mathrm{Ref}}$ than others. The final choice of the reference spectrum is informed from comparing the $\mathrm{SCD}_{\mathrm{Ref}}$, determined using the iterative method presented here, to the $\mathrm{SCD}_{\mathrm{Ref}}$ predicted by the WACCM a priori profile (see Sect. 2.4.1, profile 2), which assumes a median $\mathrm{BrO}$ abundance. The ratio of $\mathrm{SCD}_{\text {Ref }}$ divided by the $\mathrm{BrO} \mathrm{VCD}$ corresponds to the AMF of the reference spectrum, which in the case of our case study was $\sim 1.2$. The following criteria are applied to select a reference spectrum: (1) the $S C D_{\text {Ref }}$ needs to be consistent with the AMF for the a posteriori $\mathrm{BrO}$ profile, as well as (2) be within $\pm 1 \times 10^{13}$ molec $\mathrm{cm}^{-2}$ of the WACCM profile increased by $40 \%$ (see Sect. 2.4.1). Figure S5 shows the results from this approach for multiple zenith spectra (potential references) on the case study day, and thus illustrates the need for active measures, such as the above, to build internal consistency between the $\mathrm{BrO} \mathrm{SCD}_{\text {Ref }}, \mathrm{BrO} \mathrm{VCD}, \mathrm{AMF}$, and forward RTM calculations of the a priori and a posteriori $\mathrm{BrO}$ profiles. The results presented in this paper are produced from a single reference spectrum (see Sect. 2.3); however, other references that pass the above quality assurance criteria would not alter our conclusions. Selecting another reference spectrum that meets the aforementioned criteria only increases the variability in the derived VCD by less than $9 \times 10^{12} \mathrm{molec}^{-2}$ (for any given single scan), and changing the a priori assumption has also only a small effect on the VCDs $\left( \pm 1.5 \times 10^{12}\right.$ molec $\mathrm{cm}^{-2}$ from average value).

\section{Iterative approach}

The value of $\mathrm{SCD}_{\mathrm{Ref}}$ is determined here by iteratively running the optimal estimation inversion on the MAX-DOAS scan containing the reference spectrum; this process is shown as a flow chart in Fig. 3a. The initial value for $\mathrm{SCD}_{\mathrm{Ref}}$ is determined from the a priori profile, and subsequent $\mathrm{SCD}_{\mathrm{Ref}}$ values are determined from the a posteriori profile of the inversion returned from the previous iteration. For each iteration only $\mathrm{SCD}_{\mathrm{Ref}}$ changes; the a priori profile remains constant. After multiple iterations this method converges on a $\mathrm{SCD}_{\text {Ref }}$ that minimizes the differences between the measured

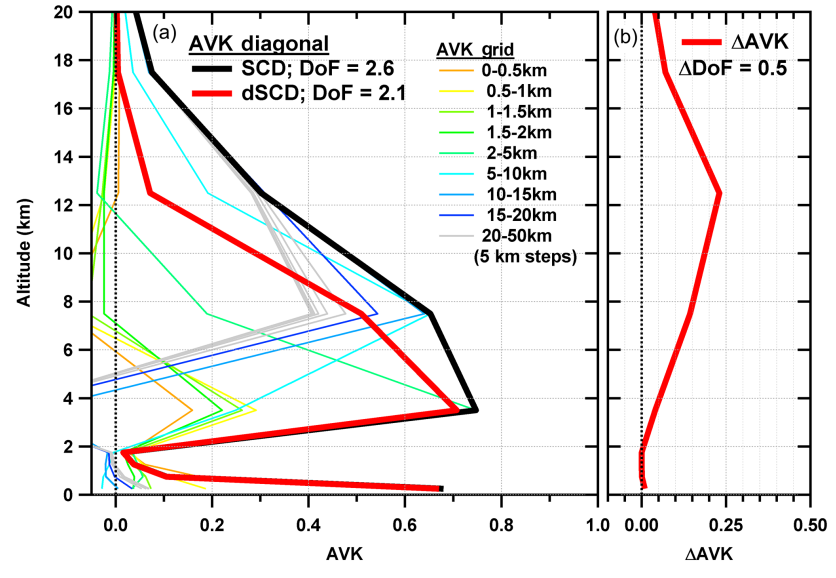

Figure 4. Characterizing the retrieval averaging kernel (AVK) and degrees of freedom (DoF). (a) AVK output for an inversion of $\mathrm{BrO}$ $\mathrm{SCDs}$ (at $\mathrm{SZA}=25^{\circ}$ ) as a function of altitude. The colored traces represent the individual altitude grids of the inversion accounting for $\mathrm{SCD}_{\mathrm{Ref}}$; the thick black trace is the diagonal of the AVK matrix; the thick red trace is the diagonal of the AVK matrix from the inversion not accounting for $\mathrm{SCD}_{\mathrm{Ref}}$. Panel (b) shows the difference between the two AVK diagonals as a function of altitude.

and forward calculated scan SCD inputs. This value is then used as input for the inversion of the rest of the MAX-DOAS scans throughout the day. Figure $3 \mathrm{~b}$ depicts the iterative refinement of the $S C D_{\text {Ref }}$ and corresponding VCD for the reference chosen as most ideal for this case study.

\section{Results and discussion}

\subsection{Characterizing the BrO profile retrieval}

Figure 4 compares the AVK resulting from the OE inversion of BrO SCDs constructed by accounting for $\mathrm{SCD}_{\mathrm{Ref}}$ (addition of this value to the measured dSCD output from the DOAS analysis prior to inversion) vs. not accounting for $\mathrm{SCD}_{\text {Ref }}$ (where $\mathrm{SCD}=\mathrm{dSCD}$ and with appropriate modification of the weighting functions to reflect this treatment). The largest differences are seen at low SZA in the FT. Figure 4a shows the AVK matrix, which gives an indication as to how much information can be derived from the measurements at specific altitudes, as a function of altitude for the inversion (at $\mathrm{SZA}=25^{\circ}$ ) accounting for $\mathrm{SCD}_{\mathrm{Ref}}$ (different colored thin lines) along with the diagonal of this matrix (thick black line) and the diagonal for the inversion not accounting for $\mathrm{SCD}_{\mathrm{Ref}}$ (thick red line). Figure $4 \mathrm{~b}$ shows the difference between the two diagonals as a function of altitude. Also listed in Fig. 4 are DoFs for the different retrieval methods, which, when $\mathrm{SCD}_{\mathrm{Ref}}$ is properly accounted for, demonstrate an increase of 0.5 (mostly coming from the FT). For these reasons, we chose to include $\mathrm{SCD}_{\mathrm{Ref}}$ in the inversion of the measured $\mathrm{BrO}$ dSCDs in order to further maximize the sensitivity of these measurements towards the FT. Additional information 


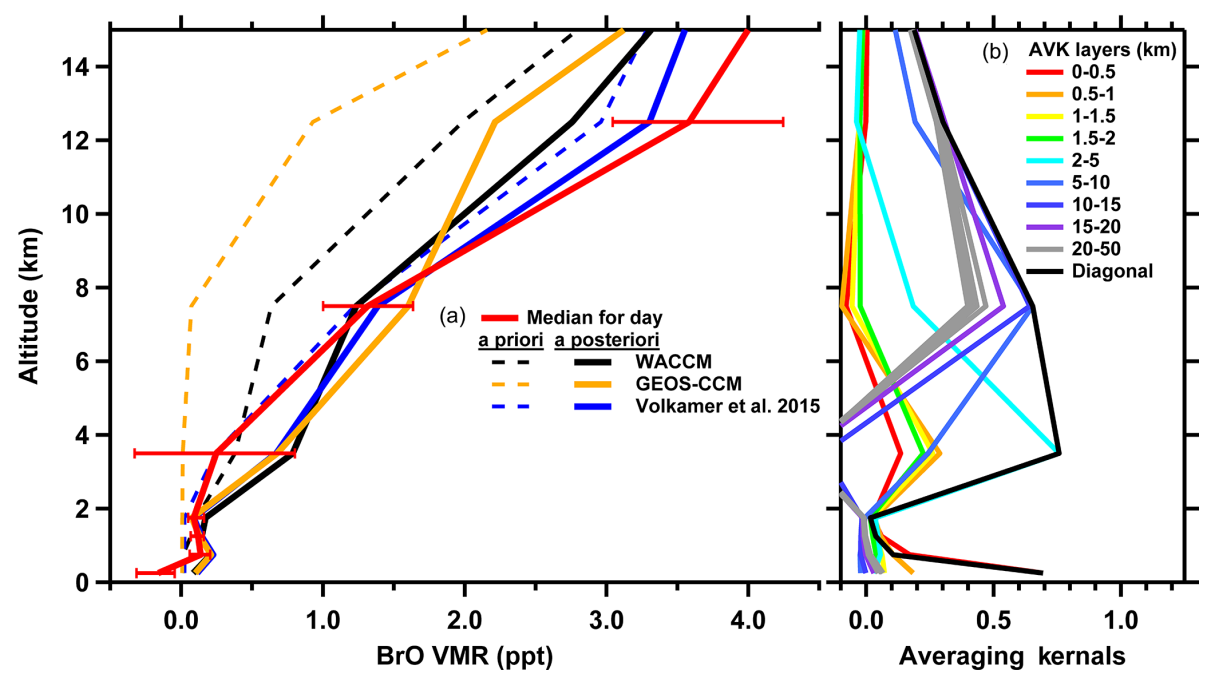

Figure 5. BrO profiles for a single MAX-DOAS measurement scan at SZA $\sim 23^{\circ}$ around solar noon. Panel (a) contains three of the a priori profiles tested (dashed lines) and the respective a posteriori profiles (solid lines); colors correspond to use of WACCM (black), GEOS-CCM (orange), and TORERO RF12 (blue) as a priori information. Panel (b) contains the AVK from the inversion using the WACCM profile as the a priori, and gives an indication of the amount of information coming from the measurements as a function of altitude.

on the DoFs and inversion RMS for these retrievals throughout the case study day is found in Fig. S6. It should be noted that the presence of even moderate aerosol loads would significantly impact the ability to derive vertical profiles extending into the FT but column-integrated information would remain intact.

Recently, Volkamer et al. (2015) reported significant sensitivity of ship MAX-DOAS profiles to the magnitude of $\mathrm{SCD}_{\mathrm{Ref}}$ over oceans. For several case studies independent aircraft measurements above the ship show that a significant trace gas partial column resides above the BL (IO and glyoxal). They find that while the BL VMR is insensitive to the value of $\mathrm{SCD}_{\text {Ref }}$, the partial tropospheric VCD can be impacted by up to a factor of 2-3. During this study the impact of using $\mathrm{BrO}$ dSCDs, rather than SCDs, in the inversion leads to an average percent difference in the $\mathrm{BrO}$ VCD derived for each MAX-DOAS scan of $\sim 30 \%$. The average VCDs were $2.1 \times 10^{13}$ and $2.3 \times 10^{13}$ molec cm$^{-2}$ (integrated from 0 to $15 \mathrm{~km}$ ) when using dSCDs or SCDs (only $\sim 10 \%$ difference). This reflects that the inversion based on dSCDs (not accounting for $\mathrm{SCD}_{\mathrm{Ref}}$ ) produced highly variable FT VCDs throughout the case study day, and that this variability is reduced for the SCD-based inversion.

The reduced variability in the BrO VCD compared to the other gases investigated by Volkamer et al. (2015) is probably due to the fact that no $\mathrm{BrO}$ was detected in the $\mathrm{BL}$ in either case study. For glyoxal and IO about $50 \%$ of the VCD resides near the instrument altitude (Volkamer et al., 2015). This BL contribution also adds offsets to the SCDs for the higher EAs that "partially obstruct" the view of the FT, and makes FT partial columns subject to larger error bars. The lack of BrO in the BL seems to simplify measure- ments of FT partial columns from the ground. The Volkamer et al. (2015) case studies in combination with our results thus suggest that MAX-DOAS instruments, which measure FT partial columns of gases other than BrO, should actively avoid complications from absorbers near instrument altitude, for example by placing the instrument on mountaintops. The lack of aerosols from high mountaintops has the additional benefit of increased sensitivity to measure profiles for $\mathrm{BrO}$ and other gases.

\subsection{BrO VCDs and vertical profiles}

Figure 5 shows the results from the inversions using the three different a priori profiles. Figure 5a shows the a priori profiles, and the a posteriori vertical profiles corresponding to one scan at $\sim 23^{\circ}$ SZA (around solar noon), as well as the median profile from all profiles. A total of 45 profiles, corresponding to $\mathrm{SZA}<70^{\circ}$ for each a priori case, were combined to create the median $\mathrm{BrO}$ vertical profile for the case study day (Fig. 5). The median profile was used for the modeling results and discussion in Sect. 3.4. Figure 5b shows the AVK (see Sect. 2.4.1) from the inversion using the unmodified WACCM BrO output as the a priori profile. In an ideal scenario, the AVK for each layer peaks near unity within that layer. The derived vertical profiles show only slight dependence on the a priori profile with a maximum average difference between a posteriori profiles of $\sim 0.6 \mathrm{ppt}$ at altitudes $<15 \mathrm{~km}$ for the entire day. These profile differences have only a small effect on the free-tropospheric VCDs, i.e., $<20 \%$ difference for SZA $<70^{\circ}$. The AVK peaks twice once in the lowest layer (from the lowest looking elevation angles) and again between 5 and $20 \mathrm{~km}$ - which reflects the combination of the optimization of the radiative transfer grid 
and the measurement sensitivity. This is interpreted as an indication that the DoFs remaining after accounting for the peak at instrument altitude correspond to the FT. Figure S7 contains a comparison of the a posteriori profile derived $\mathrm{BrO}$ dSCDs and the measured dSCDs (Fig. S7a and b) and the corresponding RMS difference between measured and calculated dSCDs in Fig. S7c.

This inversion procedure allows for the determination of the diurnal variation in the BL $(0-1 \mathrm{~km})$, FT $(1-15 \mathrm{~km})$, and total VCDs for BrO. These results, corresponding to the inversion utilizing WACCM output as the a priori profile, are found in Fig. 6b along with the corresponding DoFs (Fig. 6a). The errors bars on the tropospheric and stratospheric VCDs reflect the range of derived values resulting from the use of different a priori assumptions. The retrieved diurnal variation in the free-tropospheric $(1-15 \mathrm{~km}) \mathrm{BrO} \mathrm{VCD}$ follows that of the total VCD with an average of $53 \%$ contribution to the total and varying between 47 and $57 \%$ throughout the day; this corresponds to a daytime average VCD of $\sim 2.3 \pm 0.16 \times 10^{13} \mathrm{molec}^{-2}$, where the error reflects the average error on the VCD as seen in Fig. 6b. The overall error on the average VCD is $\sim 0.7 \times 10^{13}$ molec $\mathrm{cm}^{-2}$ and takes into account change in the VCD when assuming the maximum profile error given by the $\mathrm{OE}$ inversion. This treatment is expressed in Eq. (3).

Total error $=\frac{\left(\mathrm{VCD}_{\text {Prf }}-\mathrm{VCD}_{\text {Prf }+\mathrm{OE} \text { err }}\right)}{2}$,

where VCDPrf is the VCD calculated directly from the OE inversion a posteriori, $\mathrm{VCD}$ Prf+OE err is the VCD calculated from the $\mathrm{OE}$ inversion a posteriori profile plus the $\mathrm{OE}$ error of that profile, and the factor of 2 reflects that the OE inversion error at each altitude covers oscillations both higher and lower than the retrieved profile at that point.

The tropospheric VCD of $\sim 2.3 \pm 0.7 \times 10^{13}{\text { molec } \mathrm{cm}^{-2}}^{-2}$ $\mathrm{BrO}$ derived from this study falls in the range of other currently reported measurements, which span from $\sim 1$ to $3 \times 10^{13}$ molec $\mathrm{cm}^{-2}$ (Van Roozendael et al., 2002; Salawitch et al., 2005; Theys et al., 2007, 2011; Coburn et al., 2011; Volkamer et al., 2015; Wang et al., 2015). The observed tropospheric BrO VCD is consistent with the VCD of $2.0 \times 10^{13}$ molec $\mathrm{cm}^{-2}$ measured by the same instrument during a previous study in the same location (Coburn et al., 2011). This value is higher than other ground-based measurements in the Southern Hemisphere tropics (Theys et al., 2007), which reported tropospheric VCDs of 1.1$1.2 \times 10^{13} \mathrm{molec}^{-2}$. Aircraft profiles over the Pacific Ocean have reported variable $\mathrm{BrO}$ VCDs ranging from 1.0 to $1.7 \times 10^{13}$ molec $\mathrm{cm}^{-2} \mathrm{BrO}$, and a campaign average of $1.3 \pm 0.2 \times 10^{13}$ molec $^{-2}$ BrO (Volkamer et al., 2015; Wang et al., 2015). While it appears that the BrO VCD is highly variable, depending on the location and time of measurement, the average BrO VCD measured by the GOME2 (Global Ozone Monitoring Experiment-2) satellite for January/February in the tropics $\left(30^{\circ} \mathrm{N}-30^{\circ} \mathrm{S}\right.$; longitudinal av-

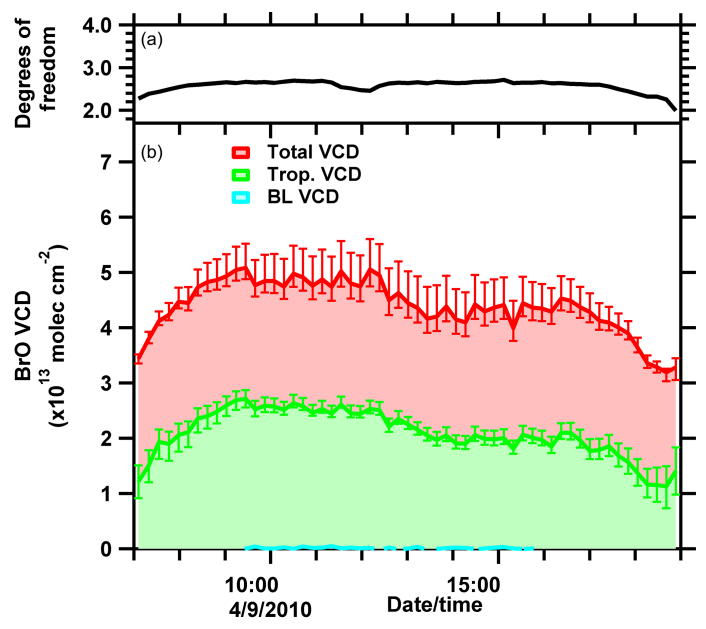

Figure 6. Diurnal variation in the $\mathrm{BrO}$ vertical profiles represented as partial VCDs for the BL $(0-1 \mathrm{~km})$, troposphere $(0-15 \mathrm{~km})$, total $(0-50 \mathrm{~km})(\mathbf{b})$, and the total DoFs from the inversion for each profile in (a). The error bars on the VCDs indicate the range of values retrieved using the three different a priori profiles.

erage) is $1.6 \times 10^{13} \mathrm{molec}^{-2}$, in reasonably close agreement with ground and aircraft studies. Much of the current knowledge of bromine chemistry in the upper tropospherelower stratosphere (UTLS) is currently based on balloonborne direct-sun BrO measurements (Pundt et al., 2002; Dorf et al., 2006), which have found an order of magnitude lower $\mathrm{BrO}$. This lower $\mathrm{BrO}$ is - at least in part - due to atmospheric variability (see e.g., Wang et al., 2015; Schmidt et al., 2016). Ground, aircraft and satellite measurements consistently support elevated $\mathrm{BrO}$ in the FT. A reassessment of halogen chemistry in the UTLS (bromine and iodine) seems warranted (Volkamer et al., 2015; Wang et al., 2015; SaizLopez et al., 2015).

\subsection{Comparison with models}

Global model results for BrO VCDs generally predict much lower columns than observed in this study. Yang et al. (2005), using the p-TOMCAT model, found midlatitude values of $\sim 0.4 \times 10^{13} \mathrm{molec} \mathrm{cm}^{-2}$ for spring/summer months and Parrella et al. (2012), using GEOS-Chem, reported values of $<1 \times 10^{13} \mathrm{molec} \mathrm{cm}^{-2}$ for the entire year for the Northern Hemisphere midlatitudes. The value from Parella et al. (2012) is slightly more comparable to that predicted by WACCM for the case study day $\left(\sim 1 \times 10^{13}\right.$ molec $\mathrm{cm}^{-2}$, see Fig. S3). Wang et al. (2015) reported sensitivity in the predicted $\mathrm{BrO}$ to updated heterogeneous chemistry of bromine (Ammann et al., 2013). Recently, Schmidt et al. (2016) incorporated the enhanced heterogeneous chemistry (EHC) scheme into GEOS-Chem. The EHC bromine chemistry mechanism produces higher average tropospheric $\mathrm{BrO}$ columns, which are more consistent with our observations. They found that average tropospheric $\mathrm{BrO}$ concentra- 
Table 2. Summary of mercury reactions and rate coefficients used in the box model.

\begin{tabular}{|c|c|c|}
\hline Reaction & $\begin{array}{l}\text { Rate or equilibrium } \\
\text { coefficient }^{2}\end{array}$ & Reference \\
\hline $\mathrm{Hg}^{0}+\mathrm{O}_{3} \rightarrow \mathrm{HgO}+\mathrm{O}_{2}$ & $3 \times 10^{-20}$ & Hall (1995) \\
\hline $\mathrm{HgO}_{(\mathrm{g})} \leftrightarrow \mathrm{HgO}_{(\mathrm{aq})}$ & $K_{\mathrm{eq}}^{1}$ & Rutter and Schauer (2007) \\
\hline $\mathrm{HgO}_{(\mathrm{aq})} \rightarrow \mathrm{Hg}_{(\mathrm{g})}^{0}$ & $1.12 \times 10^{-5}$ & Costa and Liss (1999) \\
\hline $\mathrm{Hg}^{0}+\mathrm{Br} \stackrel{\mathrm{M}}{\longrightarrow} \mathrm{HgBr}$ & $1.46 \times 10^{-32} \cdot\left(\frac{T}{298}\right)^{-1.86} \cdot[\mathrm{M}]$ & Donohoue et al. (2006) \\
\hline $\mathrm{HgBr}+\mathrm{M} \rightarrow \mathrm{Hg}^{0}+\mathrm{Br}+\mathrm{M}$ & $4.0 \times 10^{9} \cdot \exp \left(\frac{-7292}{T}\right)$ & Goodsite et al. (2012) \\
\hline $\operatorname{HgBr}_{(\mathrm{g})} \leftrightarrow \operatorname{HgBr}_{(\mathrm{aq})}$ & $K_{\mathrm{eq}}^{1}$ & Rutter and Schauer (2007) \\
\hline $\mathrm{HgBr}+Y^{3} \rightarrow \operatorname{HgBr} Y$ & $2.5 \times 10^{-10} \cdot\left(\frac{T}{298}\right)^{-0.57}$ & Goodsite et al. (2004) \\
\hline$\rightarrow \mathrm{Hg}^{0}+\mathrm{Br}_{2}$ & $3.9 \times 10^{-11}$ & Balabanov et al. (2005) \\
\hline $\operatorname{HgBr}_{(\mathrm{g})} \leftrightarrow \operatorname{HgBr} Y_{(\mathrm{aq})}$ & $K_{\mathrm{eq}}^{1}$ & Rutter and Schauer (2007) \\
\hline $\mathrm{HgBr}_{(\mathrm{aq})} \rightarrow \mathrm{Hg}_{(\mathrm{g})}^{0}$ & $1.12 \times 10^{-5}$ & Costa and Liss (1999) \\
\hline $\mathrm{HgBr}+Y^{\prime 4} \rightarrow \operatorname{HgBr} Y^{\prime}$ & $1 \times 10^{-10}$ & Dibble et al. (2012) \\
\hline $\operatorname{HgBr}_{(\mathrm{g})}^{\prime} \leftrightarrow \operatorname{HgBr}_{(\mathrm{aq})}^{\prime}$ & $K_{\mathrm{eq}}^{1}$ & Rutter and Schauer (2007) \\
\hline $\mathrm{HgBr}_{(\mathrm{aq})}^{\prime} \rightarrow \mathrm{Hg}_{(\mathrm{g})}^{0}$ & $1.12 \times 10^{-5}$ & Costa and Liss (1999) \\
\hline
\end{tabular}

tions are $\sim 50 \%$ more than predicted from the Parrella et al. (2012) bromine mechanism; this is similar to the findings from this study, where the tropospheric VCD predicted by GEOS-Chem (which uses the Parrella et al. (2012) bromine chemistry) is $\sim 30 \%$ lower than the measured VCD. Notably, different representations of halogen chemistry can result in very different BrO vertical profile shapes (Sander et al., 2003; Fernandez et al., 2014; Long et al., 2014; Liang et al., 2014), despite an apparently good agreement $\left(\sim 1 \times 10^{13}\right.$ molec $\left.\mathrm{cm}^{-2}\right)$ in the BrO VCD at tropical latitudes. The ability to predict $\mathrm{BrO}$ vertical profiles is particularly relevant to predict distributions of oxidized mercury in the lower troposphere (see Sect. 3.4.2).

\subsection{Mercury modeling}

A detailed description of the box model utilized in this study to assess the oxidation pathways of mercury is found in Sect. S4. Table 2 gives an overview of the reactions controlling the cycling of atmospheric mercury included in the box model and Fig. S8 contains the vertical profiles of modeled and measured parameters used as input to the box model. In general, the mercury modeling scheme employed in this study follows that as set forth in previous works (Selin et al., 2007; Holmes et al., 2009, 2010; Wang et al., 2015).

\subsubsection{Mercury oxidation rates}

The primary finding from a comparison of the $\mathrm{Hg}^{0}$ oxidation rates for the two radical species tested in this study $\left(\mathrm{Br}\right.$ and $\left.\mathrm{O}_{3}\right)$ is that the reaction with $\mathrm{Br}$ domi- nates the overall rate throughout the troposphere for the conditions tested by this case study, independent of initial $\mathrm{BrO}$ vertical profile used. The column integral rate is $7.8 \times 10^{4}$ molec $\mathrm{cm}^{-2} \mathrm{~s}^{-1}$ for $\mathrm{O}_{3}$, while the $\mathrm{Br}$ rates are $3.5 \times 10^{5}$ and $3.7 \times 10^{5}$ molec $\mathrm{cm}^{-2} \mathrm{~s}^{-1}$ for the BrO vertical profiles from the MAX-DOAS measurements and GEOSChem, respectively. Preliminary tests included chlorine $(\mathrm{Cl})$ radicals as an additional oxidant using a vertical distribution estimated for the tropical troposphere (Wang et al., 2015). However, this reaction was deemed unimportant, and is thus not included here, due to the column integral oxidation rates being factors of 18 and 5 lower than column rates for $\mathrm{Br}$ and $\mathrm{O}_{3}$, respectively. The reaction rates from $\mathrm{Br}$ are at least a factor of 3 greater than the contribution from $\mathrm{O}_{3}$.

The vertically resolved rates are shown in Fig. 7a for both reactions: $\mathrm{Br}$ (solid blue and dotted pink traces representing the BrO profiles from the MAX-DOAS measurements and GEOS-Chem, respectively, used to derive the Br radical concentrations) and $\mathrm{O}_{3}$ (red trace), reflecting the contributions of these reactions at different altitudes. Also included in Fig. 7b are the corresponding lifetimes of GEM (as a function of altitude) against oxidation by the two molecules. Only in the lowest layers of the atmosphere do the rates of oxidation through reaction with $\mathrm{O}_{3}$ become comparable or greater than those of the reaction with $\mathrm{Br}$. However, it should be noted that for altitudes $<4 \mathrm{~km}$, where the rate of reaction with $\mathrm{O}_{3}$ dominates, the $\mathrm{BrO}$ VMR is $<0.03$ pptv, while the $\mathrm{O}_{3} \mathrm{VMR}$ is $\sim 50 \mathrm{ppbv}$, and in cases where reaction with $\mathrm{Br}$ dominates (still at altitudes $<4 \mathrm{~km}$ ) the $\mathrm{BrO} \mathrm{VMR}$ is still $<0.3$ pptv. The BrO vertical profile from the MAX-DOAS instrument 


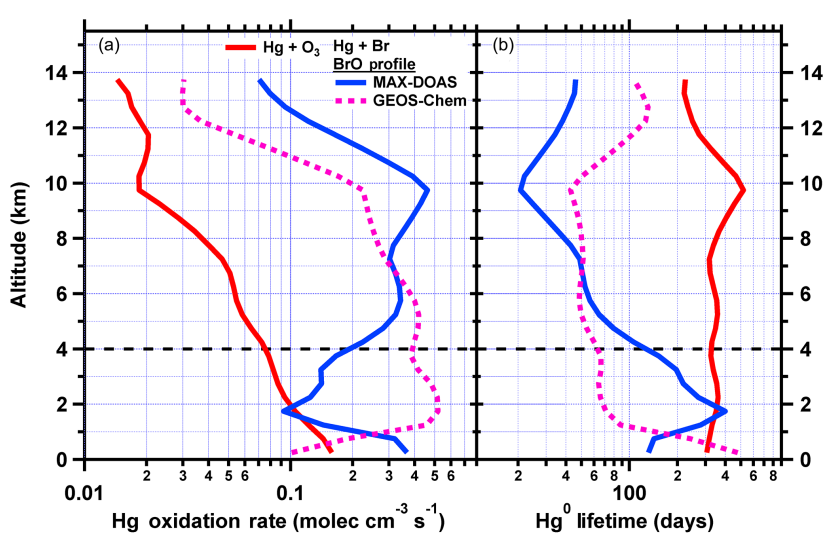

Figure 7. Box model results of the rate of mercury oxidation as a function of altitude for two species: (1) ozone (red); and (2) bromine radicals (solid blue: MAX-DOAS; dashed pink: GEOS-Chem) (a); the corresponding lifetimes are found in (b). The black dashed line at $4 \mathrm{~km}$ shows where measurement sensitivity starts to drop because of the decreasing amount of $\mathrm{BrO}$ (the measured parameter) in the lower layers of the atmosphere.

below $4 \mathrm{~km}$ contains the highest amount of uncertainty because $\mathrm{BrO}$ is essentially zero within the variability of the measurements. The column integral rates of oxidation based on the MAX-DOAS measurements and the $\mathrm{BrO}$ profile from GEOS-Chem are actually quite similar (only $\sim 5 \%$ difference), which is most likely due to the additional bromine chemistry included in this model (see Sect. 2.2) as compared to other models (e.g., GEOS-CCM); however, the discrepancies in the vertical distribution of $\mathrm{BrO}$ lead to a mismatch in the altitudes at which the oxidation can occur. For both $\mathrm{BrO}$ profiles, the reaction with $\mathrm{Br}$ dominates above $4 \mathrm{~km}$ (indicated by the black dashed line in Fig. 7). Altitudes above $4 \mathrm{~km}$ are responsible for $\sim 72 \%$ of the column integral rate of GEM oxidation (through reaction with $\mathrm{Br}$ ) based on the MAX-DOAS measurements, while that value decreases to $\sim 56 \%$ for the bromine profile from GEOS-Chem.

Additional differences between column oxidation rates for the MAX-DOAS and GEOS-Chem BrO profiles exists at altitudes $<4 \mathrm{~km}$, where the MAX-DOAS measurements find no $\mathrm{BrO}$ and GEOS-Chem predicts up to $0.75 \mathrm{pptv}$. Similar to the findings of this study, other publications have put upper limits on marine boundary layer (MBL) $\mathrm{BrO} \sim 0.5 \mathrm{pptv}$ (Gomez-Martin et al., 2013; Wang et al., 2015; Volkamer et al., 2015).

\subsubsection{Mercury oxidation pathways}

Figure 8 shows the results of the "traditional" (Fig. 8a) and "revised" (Fig. 8b) $\mathrm{HgBr}$ scavenging schemes (see Sect. S4 for descriptions) on the rate of GEM oxidation as a function of altitude. In each panel, contributions of individual molecules (colored lines) are shown along with the total removal rate (black lines). Figure $8 \mathrm{c}$ shows the vertical pro- file of the ratio of the "revised" total rate to "traditional" total rate, which demonstrates the enhanced oxidation of $\mathrm{HgBr}$ when considering the additional scavenging reactions. In the "traditional" model the percent contributions to the column integrated rate of oxidation of $\mathrm{HgBr}$ are 57.5 and $42.5 \%$ for $\mathrm{OH}$ and $\mathrm{Br}$, respectively, and in the "revised" model the percent contributions are as follows: $71.3 \%\left(\mathrm{NO}_{2}\right), 21.3 \%$ $\left(\mathrm{HO}_{2}\right), 4.3 \%(\mathrm{BrO}), 1.4 \%(\mathrm{OH}), 1.1 \%(\mathrm{Br}) ; 0.5 \%(\mathrm{IO})$, and $<0.1 \%$ (I). Note that mercury oxidation is initiated by reaction between Br radicals and GEM in both reaction schemes, and the additional scavenging reactions in the "revised" scheme primarily increase the overall rate of oxidation at altitudes where $\mathrm{HgBr}$ decomposition is fast. The greatest enhancement is seen below $8 \mathrm{~km}$, where the overall rate of oxidation is $\sim 100$ times faster, primarily because of the reaction of $\mathrm{HgBr}$ with $\mathrm{NO}_{2}$ and $\mathrm{HO}_{2}$.

Figure 8 also illustrates the increased number of species produced from the additional oxidation mechanisms, some of which may have physical and chemical properties that differ from the two products of the "traditional" mode, which are also products in the "revised" scenario but are present at much lower concentrations. In the "traditional" scenario at $1 \mathrm{~km}$, the scavenging products $\mathrm{HgBrOH}$ and $\mathrm{HgBr}_{2}$ account for 96 and $4 \%$ of the total $\mathrm{HgBrX}$, respectively, and these values drop to 0.5 and $\ll 0.1 \%$ in the "revised" scenario, where $\mathrm{HgBrNO}_{2}$ accounts for $73 \%$ of $\mathrm{HgBrX}$. In the "revised" scenario, $\mathrm{HgBrNO}_{2}$ remains the major product throughout the atmosphere, but at free-tropospheric altitudes $\mathrm{HgBrHO}_{2}$ also contributes significantly at $37 \%$, compared to $\mathrm{HgBrNO}_{2}$ at $52 \%$. There are currently no observations of the molecular composition of GOM with which to evaluate these simulated product distributions.

\subsubsection{Mercury lifetime with respect to oxidation}

The above oxidation rates correspond to a minimum lifetime of GEM with respect to oxidation by bromine radicals of $\sim 20$ days in the FT (based on the MAX-DOAS measurements). The average total $\left(\mathrm{Hg}^{0}+\mathrm{Br}\right.$ and $\left.\mathrm{Hg}^{0}+\mathrm{O}_{3}\right)$ tropospheric column lifetimes are 38 and 54 days (altitudes $>4 \mathrm{~km}$ ) for the scenarios including $\mathrm{BrO}$ profiles from the MAX-DOAS measurements and GEOS-Chem, respectively, where in both cases the contributions from the reactions with $\mathrm{O}_{3}$ are the same and the differences are owing to the differing amounts of $\mathrm{Br}$ radicals. This is much shorter than the currently expected atmospheric lifetime on the order of several months. However, the box model only accounts for partitioning of the GOM species between the gas phase and aerosols; once they are in the aqueous phase they can be photoreduced to GEM, which can then subsequently return to the gas phase (Costa and Liss, 1999), thus extending the effective lifetime significantly beyond that calculated above. The kinetic coefficients for reactions involving $\mathrm{HgBr}$ come mainly from quantum chemical calculations, which have significant uncertainties, so the simulated 


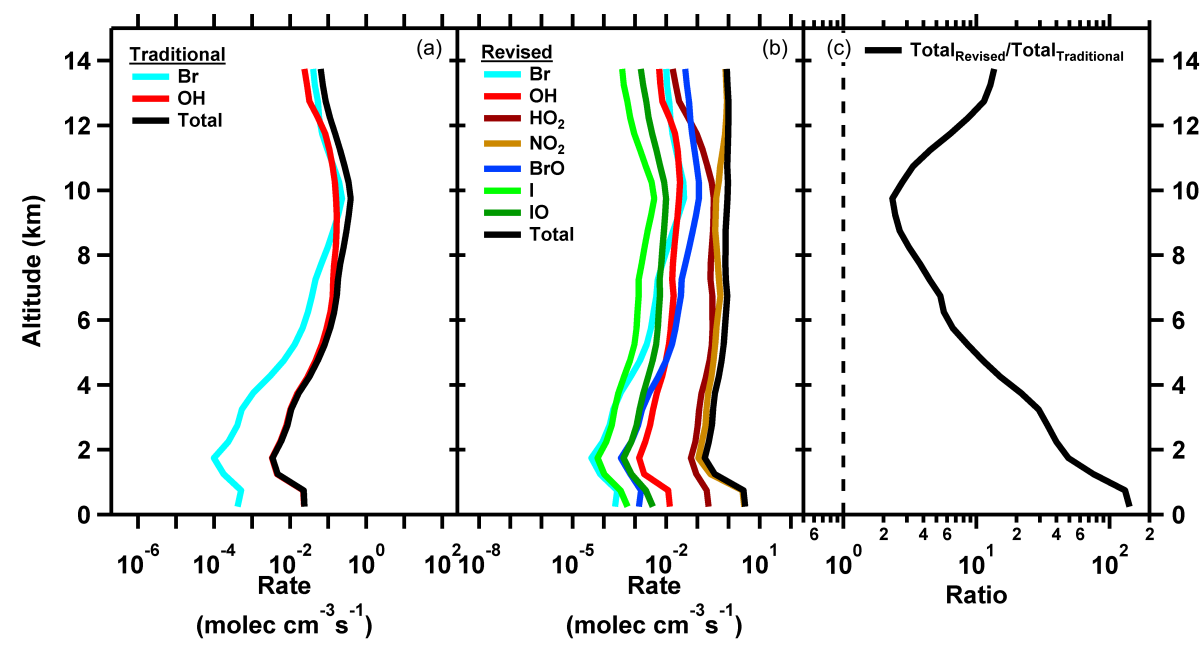

Figure 8. Box model results for the scavenging of the $\mathrm{HgBr}$ adduct as a function altitude for two different reaction schemes: traditional (a) and revised (b). Panel (c) contains the ratio of the total rates (black traces in (a) and (b) to show the enhancement in the rate of the scavenging reaction when other reactants are taken into consideration.)

GEM lifetime could be extended by reducing the rate coefficients within their uncertainties. Another possible mechanism is the photodissociation of $\mathrm{HgBrX}$ products containing species that have significant absorption cross sections in the ultraviolet-visible (UV/Vis) region of the electromagnetic radiation spectrum, e.g., $\mathrm{HgBrNO}_{2}$ and $\mathrm{HgBrHO}_{2}$, which could reproduce $\mathrm{HgBr}$. This $\mathrm{HgBr}$ could then thermally decompose to re-form GEM, or be oxidized again. Our observations are consistent with previous findings (Wang et al., 2015) that establish GEM as a chemically highly dynamic component of the FT. It is expected that GOM species will also go through additional processes in the aqueous phase, which could significantly impact the ultimate fate of the mercury.

\subsection{Atmospheric implications}

The rapid oxidation of mercury in the lower FT is of potential relevance in the SE US, where there have been several studies linking deep convective activity to the elevated levels of mercury found in rainwater (Guentzel et al., 2001; Landing et al., 2010; Nair et al., 2013). The bioaccumulation of methyl mercury in fish tissues is particularly relevant in this region, where it has been deemed unsafe to eat fish harvested from many lakes in the region (Engle et al., 2008; Liu et al., 2008). Wet deposition measurements of mercury exceed what can be explained through regional sources in the southeast. In fact, Guentzel et al. (2001) estimated that $<46 \%$ of the mercury deposited in Florida was a result of local emissions, while the other $>50 \%$ was attributed to longrange transport of mercury in the atmosphere; the transported fraction may have increased since those data were collected in the 1990s because regional US mercury emissions have declined while global emissions have risen. This attribution, coupled with mountaintop and aircraft studies locating elevated levels of GOM in the FT (Swartzendruber et al., 2006; Faïn et al., 2009; Swartzendruber et al., 2009; Lyman and Jaffe, 2012; Brooks et al., 2014; Weiss-Penzias et al., 2015, Shah et al., 2016), strongly suggests the presence of a global "pool" of mercury in the upper atmosphere that contributes to widespread mercury deposition on a local to regional scale.

On the case study day, $\mathrm{Hg}^{\mathrm{II}}$ (= GOM + PBM) concentrations at the nearly Pensacola MDN site reached $25 \mathrm{pg} \mathrm{m}^{-3}$ around midday and nearly $40 \mathrm{pg} \mathrm{m}^{-3}$ on 10 April (Fig. 9). High $\mathrm{Hg}^{\mathrm{II}}$ events in Pensacola are frequently consistent with emissions from a nearby coal-fired power plant; however about $25 \%$ of such events have significant contributions from the FT (Weiss-Penzias et al., 2011). The high $\mathrm{Hg}^{\mathrm{II}}: \mathrm{SO}_{2}$ ratios $\left(10-20 \mathrm{pg} \mathrm{m}^{-3} \mathrm{ppb}^{-1}\right)$ and high $\mathrm{NO}_{y}: \mathrm{SO}_{2}$ ratios $(3.5-$ $5.2 \mathrm{ppb} \mathrm{ppb}^{-1}$ ) recorded on 9-10 April make the power plant an unlikely source of the $\mathrm{Hg}^{\mathrm{II}}$ on these days (Fig. S9); for comparison, Weiss-Penzias et al. (2011) reported $\mathrm{Hg}^{\mathrm{II}}: \mathrm{SO}_{2}$ and $\mathrm{NO}_{y}: \mathrm{SO}_{2}$ ratios of 3.5 and 1.0, respectively, in power plant plumes. Like $\mathrm{Hg}^{\mathrm{II}}$ concentrations, ozone concentrations and $\mathrm{Hg}^{\mathrm{II}}$ dry deposition in Florida also peak in spring, all of which are consistent with a significant source of surface $\mathrm{Hg}^{\mathrm{II}}$ being from the upper troposphere (Lyman et al., 2009; Gustin et al., 2012). We use the GEOS-Chem model to further probe the sources of this $\mathrm{Hg}^{\mathrm{II}}$. Figure 9 shows that the model generally reproduces the day-to-day variability of $\mathrm{Hg}^{\mathrm{II}}$ observations during April 2010 (but not extremes), such as the low concentrations during 7-8 April and relative maxima on 5 and 10 April. In both the model and observations, $\mathrm{Hg}^{\mathrm{II}}$ concentrations rise abruptly in the morning, consistent with entrainment of $\mathrm{Hg}^{\mathrm{II}}$ aloft and unlike the other combustion tracers (e.g., $\mathrm{NO}_{y}, \mathrm{SO}_{2}$ ) that reach high concentrations at night (Fig. S9). The model does not reproduce the abrupt drop in $\mathrm{Hg}^{\mathrm{II}}$ around 18:00 CST, however, which may be partly due 


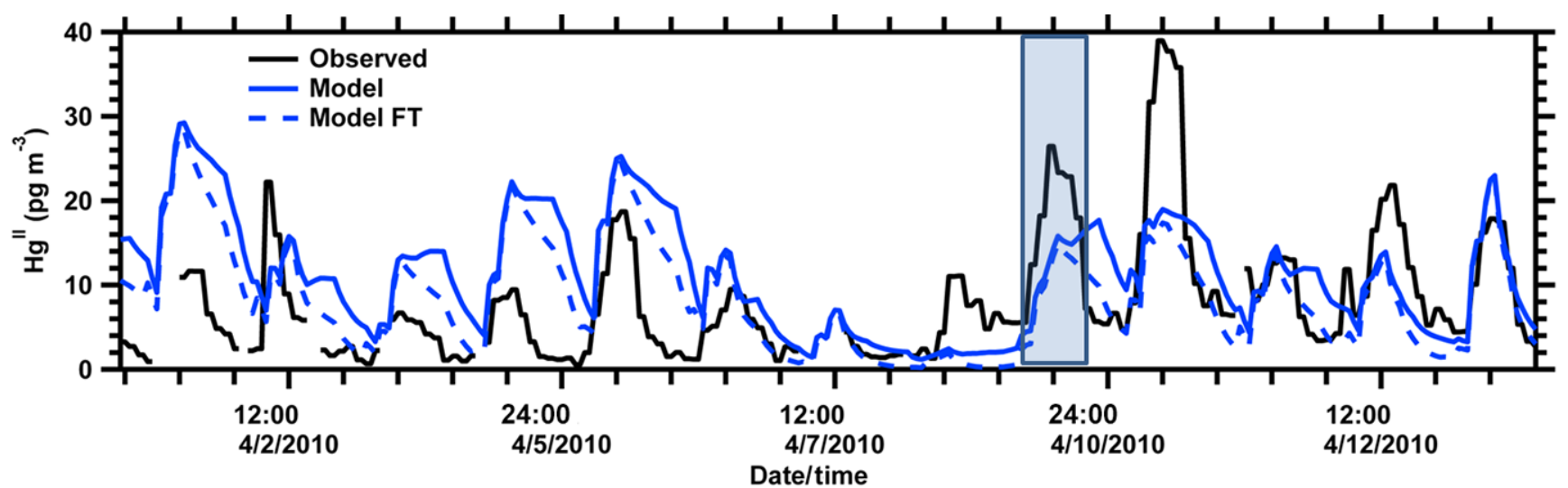

Figure 9. Observed (black solid trace) and simulated (blue traces) concentrations of oxidized mercury $(\mathrm{Hg}=\mathrm{II}=\mathrm{GOM}+\mathrm{PBM})$ during April 2010 (9 April highlighted). Model results from GEOS-Chem (solid) include a sensitivity test, labeled FT (dashed trace), in which North American anthropogenic emissions are zero and no GEM oxidation occurs in the lower troposphere $(>700 \mathrm{hPa})$; therefore all $\mathrm{Hg}^{\mathrm{II}}$ in the "FT" model is derived from oxidation of in the free troposphere or long-range transport.

to local sea breeze circulations that are evident in wind observations but not simulated at the $4^{\circ} \times 5^{\circ}$ model resolution. In addition, mixing depth errors in the driving meteorology are known to affect other species, particularly at night (Lin and McElroy, 2010; McGrath-Spangler and Molod, 2014). To assess the contribution of the FT to surface $\mathrm{Hg}^{\mathrm{II}}$ during April 2010, we conduct an additional model simulation with zero anthropogenic emissions in North America and no mercury redox chemistry in the lower troposphere $(>700 \mathrm{hPa})$. The simulation is initialized from the base run on 1 April. Due to its fast deposition, all boundary-layer $\mathrm{Hg}^{\mathrm{II}}$ in the sensitivity simulation after about 1 day originates from oxidation of GEM in the free troposphere or, less likely, from intercontinental transport of anthropogenic $\mathrm{Hg}^{\mathrm{II}}$. Figure 9 shows there is little difference between the base and sensitivity simulations, meaning that the FT is the main source of boundarylayer $\mathrm{Hg}^{\mathrm{II}}$ in the model and that variability in the FT component explains most of the day-to-day $\mathrm{Hg}^{\mathrm{II}}$ variability. Thus, the 3-D model shows that conditions on 9 April are favorable for $\mathrm{Hg}^{\mathrm{II}}$ transport to the boundary layer, exactly when the DOAS observations find that substantial amounts of $\mathrm{BrO}$ are present in the FT.

The GEM oxidation mechanism in the 3-D model corresponds to the "traditional" scheme in the box model and bromine concentrations in GEOS-Chem are lower than recent aircraft observations (Volkamer et al., 2015), so the GEM oxidation may be faster than simulated. Greater $\mathrm{Hg}^{\mathrm{II}}$ production in the FT might help correct the model's $20 \%$ low bias in mercury wet deposition over the southeastern US (Zhang et al., 2012), but this would depend on the rate of any compensating reduction reaction, as discussed above. The findings of this study indicate that the amount of bromine located in the FT can be sufficient to quickly oxidize GEM.

\section{Conclusions}

We show the benefits of determining $\mathrm{SCD}_{\mathrm{Ref}}$ to maximize the sensitivity of ground-based MAX-DOAS measurements to detect $\mathrm{BrO}$ in the FT and to improve the overall consistency of time-resolved $\mathrm{BrO}$ tropospheric VCDs. The retrieval can also be applied to other trace gases. Knowledge of $\mathrm{SCD}_{\text {Ref }}$ allows the derivation of one vertical profile for each MAX-DOAS scan throughout the day $\left(\mathrm{SZA}<70^{\circ}\right)$ and the assessment of the diurnal variation of the partial $\mathrm{BrO}$ vertical columns. Our retrieval is complementary to previous studies that have characterized the stratosphere using zenith-sky measurements under twilight conditions (Theys et al., 2007; Hendrick et al., 2007). Here, we minimize the influence of $\mathrm{O}_{3}$ absorption and the contribution of stratospheric $\mathrm{BrO}$ to the overall $\mathrm{BrO}$ signal by using $\mathrm{BrO}$ dSCDs measured at low SZA and CTM output to constrain stratospheric BrO. The FT VCDs reported here are in good agreement with the previously cited values for $\mathrm{BrO}$, with the average $\mathrm{BrO}$ FT $\operatorname{VCD}\left(\sim 2.3 \times 10^{13}\right.$ molec cm$\left.^{-2}\right)$ falling within the range reported by other studies $\left(1-3 \times 10^{13}\right.$ molec $\mathrm{cm}^{-2}$ ) (see Wang et al., 2015, and references therein). These measurements all point to the presence of background amounts of $\mathrm{BrO}$ in the FT that are larger than current models predict. The method employed here would further benefit from deployments at mountaintop sites, where aerosol shielding of the FT can be overcome and tropospheric vertical distributions assessed more frequently.

The presented box model studies indicate that, for the conditions probed, bromine radicals are the dominant oxidant for atmospheric GEM throughout the FT above the studied region. Given the similarities between the vertical profiles of $\mathrm{BrO}$ derived in this study and other profiles measured in the tropical FT (Volkamer et al., 2015; Wang et al., 2015), the results from our case study may apply more broadly, though 
past aircraft and modeling studies have reported significant variability in $\mathrm{BrO}$ and $\mathrm{Br}_{y}$ (Wang et al., 2015; Schmidt et al., 2016). The drivers for such variability deserve further investigation. Our results confirm that mercury is rapidly oxidized by bromine, and is a chemically highly dynamic species in the atmosphere. The chemical lifetime of GEM is $\sim 45$ days in the tropical FT based on calculations and vertical profiles presented in this study; longer GEM global lifetimes should thus be regarded to indicate "effective lifetimes", i.e., they are the result of rapid chemical cycling of GOM back to GEM (e.g., photoreduction; Pehkonen and Lin, 1998; Gustin et al., 2002; Tong et al., 2013). Mercury measurements during our study period show high surface $\mathrm{Hg}^{\mathrm{II}}$ concentrations that likely originate in the FT, meaning that we have observed substantial $\mathrm{BrO}$ columns under conditions favorable for $\mathrm{Hg}^{\mathrm{II}}$ transport to the boundary layer. Additionally, this study suggests that the experimental observation of elevated GOM in the FT may be linked to our incomplete understanding about tropospheric bromine sources (Swartzendruber et al., 2006; Faïn et al., 2009; Lyman and Jaffe, 2012; Wang et al., 2015) and indicates that conditions exist where the amount of bromine located in the FT above the coastal regions of the SE US is sufficient to quickly oxidize GEM to GOM. This GOM can then be wet-deposited, and can help explain the observed elevated mercury wet deposition pattern in this region. Our results highlight the need to understand $\mathrm{BrO}$ vertical profiles in the FT, and represent them in atmospheric models to understand the location where mercury is oxidized in the atmosphere, and is available for wet and dry deposition. More studies are needed to test and represent the bromine sources in atmospheric models; test atmospheric GOM abundances by field data; and clarify the chemical identity, the global distribution, and dry and wet removal processes of GOM.

\section{The Supplement related to this article is available online at doi:10.5194/acp-16-3743-2016-supplement.}

Acknowledgements. Sean Coburn is the recipient of a NASA Earth and Space Science graduate fellowship. The CU MAXDOAS instrument was developed with support from the EPRI's Technology Innovation program (EP-P27450/C13049). Financial support from EPRI (EP-P32238/C14974), US National Science Foundation (ATM-0847793, AGS-1104104), and CU Boulder startup funds is gratefully acknowledged.

Edited by: L. Carpenter

\section{References}

Aliwell, S. R., van Roozendael, M., Johnston, P. V., Richter, A., Wagner, T., Arlander, D. W., Burrows, J. P., Fish, D. J., Jones, R. L., Tørnkvist, K. K., Lambert, J.-C., Pfeilsticker, K., and Pundt, I.: Analysis of BrO in zenith-sky spectra: An Intercomparison exercise for analysis improvement, J. Geophys. Res.-Atmos., 107, ACH 10-1-ACH 10-20, doi:10.1029/2001JD000329, 2002.

Ammann, M., Cox, R. A., Crowley, J. N., Jenkin, M. E., Mellouki, A., Rossi, M. J., Troe, J., and Wallington, T. J.: Evaluated kinetic and photochemical data for atmospheric chemistry: Volume VI - heterogeneous reactions with liquid substrates, Atmos. Chem. Phys., 13, 8045-8228, doi:10.5194/acp-13-8045-2013, 2013.

Amos, H. M., Jacob, D. J., Holmes, C. D., Fisher, J. A., Wang, Q., Yantosca, R. M., Corbitt, E. S., Galarneau, E., Rutter, A. P., Gustin, M. S., Steffen, A., Schauer, J. J., Graydon, J. A., Louis, V. L. S., Talbot, R. W., Edgerton, E. S., Zhang, Y. and Sunderland, E. M.: Gas-particle partitioning of atmospheric $\mathrm{Hg}(\mathrm{II})$ and its effect on global mercury deposition, Atmos. Chem. Phys., 12, 591-603, doi:10.5194/acp-12-591-2012, 2012.

Balabanov, N., Shepler, B., and Peterson, K.: Accurate global potential energy surface and reaction dynamics for the ground state of $\mathrm{HgBr}_{2}$, J. Phys. Chem. A, 109, 8765-8773, doi:10.1021/jp0534151, 2005.

Bogumil, K., Orphal, J., Homann, T., Voigt, S., Spietz, P., Fleischmann, O., Vogel, A., Hartmann, M., Kromminga, H., Bovensmann, H., Frerick, J., and Burrows, J.: Measurements of molecular absorption spectra with the SCIAMACHY pre-flight model: instrument characterization and reference data for atmospheric remote-sensing in the $230-2380 \mathrm{~nm}$ region, J. Photochem. Photobiol. A, 157, 167-184, doi:10.1016/S1010-6030(03)00062-5, 2003.

Brooks, S., Ren, X., Cohen, M., Luke, W. T., Kelley, P., Artz, R., Hynes, A., Landing, W., and Martos, B.: Airborne Vertical Profiling of Mercury Speciation near Tullahoma, TN, USA, Atmosphere, 5, 557-574, doi:10.3390/atmos5030557, 2014.

Bullock, O.: Modeling assessment of transport and deposition patterns of anthropogenic mercury air emissions in the United States and Canada, Sci. Total Environ., 259, 145-157, 2000.

Chance, K. and Spurr, R.: Ring effect studies: Rayleigh scattering, including molecular parameters for rotational Raman scattering, and the Fraunhofer spectrum, Appl. Optics, 36, 52245230, doi:10.1364/AO.36.005224, 1997.

Coburn, S., Dix, B., Sinreich, R., and Volkamer, R.: The CU ground MAX-DOAS instrument: characterization of RMS noise limitations and first measurements near Pensacola, FL of BrO, IO, and CHOCHO, Atmos. Meas. Tech., 4, 2421-2439, doi:10.5194/amt-4-2421-2011, 2011.

Corbitt, E. S., Jacob, D. J., Holmes, C. D., Streets, D. G., and Sunderland, E. M.: Global Source-Receptor Relationships for Mercury Deposition Under Present-Day and 2050 Emissions Scenarios, Environ. Sci. Technol., 45, 10477-10484, doi:10.1021/es202496y, 2011.

Costa, M. and Liss, P. S.: Photoreduction of mercury in seawater and its possible implications for $\mathrm{Hg}^{0}$ air-sea fluxes, Mar. Chem., 68, 87-95, doi:10.1016/S0304-4203(99)00067-5, 1999.

Dibble, T. S., Zelie, M. J., and Mao, H.: Thermodynamics of reactions of $\mathrm{ClHg}$ and $\mathrm{BrHg}$ radicals with atmospherically abundant free radicals, Atmos. Chem. Phys., 12, 10271-10279, doi:10.5194/acp-12-10271-2012, 2012. 
Dix, B., Baidar, S., Bresch, J. F., Hall, S. R., Schmidt, K. S., Wang, S., and Volkamer, R.: Detection of iodine monoxide in the tropical free troposphere, P. Natl. Acad. Sci. USA, 110, 2035-2040, doi:10.1073/pnas.1212386110, 2013.

Donohoue, D., Bauer, D., Cossairt, B., and Hynes, A.: Temperature and pressure dependent rate coefficients for the reaction of $\mathrm{Hg}$ with $\mathrm{Br}$ and the reaction of $\mathrm{Br}$ with $\mathrm{Br}$ : A pulsed laser photolysispulsed laser induced fluorescence study, J. Phys. Chem. A, 110, 6623-6632, doi:10.1021/jp054688j, 2006.

Dorf, M., Bösch, H., Butz, A., Camy-Peyret, C., Chipperfield, M. P., Engel, A., Goutail, F., Grunow, K., Hendrick, F., Hrechanyy, S., Naujokat, B., Pommereau, J.-P., Van Roozendael, M., Sioris, C., Stroh, F., Weidner, F., and Pfeilsticker, $\mathrm{K}$.: Balloon-borne stratospheric $\mathrm{BrO}$ measurements: comparison with Envisat/SCIAMACHY BrO limb profiles, Atmos. Chem. Phys., 6, 2483-2501, doi:10.5194/acp-6-2483-2006, 2006.

Edgerton, E. S., Hartsell, B. E., and Jansen, J. J.: Mercury speciation in coal-fired power plant plumes observed at three surface sites in the southeastern US, Environ. Sci. Technol., 40, 4563-4570, doi:10.1021/es0515607, 2006.

Engle, M. A., Tate, M. T., Krabbenhoft, D. P., Kolker, A., Olson, M. L., Edgerton, E. S., DeWild, J. F., and McPherson, A. K.: Characterization and cycling of atmospheric mercury along the central US Gulf Coast, Appl. Geochem., 23, 419-437, doi:10.1016/j.apgeocliem2007.12.024, 2008.

Eyring, V., Shepherd, T., and Waugh, D. (Eds.): SPARC CCMVal Report on the Evaluation of Chemistry-Climate Models, SPARC Report No. 5, WCRP-30/2010, WMO/TD - No. 40, http:// www.sparc-climate.org/publications/sparc-reports/ (last access: March 2016), 2010.

Faïn, X., Obrist, D., Hallar, A. G., Mccubbin, I., and Rahn, T.: High levels of reactive gaseous mercury observed at a high elevation research laboratory in the Rocky Mountains, Atmos. Chem. Phys., 9, 8049-8060, doi:10.5194/acp-9-8049-2009, 2009.

Fayt, C. and van Roozendael, M.: WinDoas 2.1 - Software User Manual, BIRA-IASB, Belgium, 2001.

Fernandez, R. P., Salawitch, R. J., Kinnison, D. E., Lamarque, J.-F., and Saiz-Lopez, A.: Bromine partitioning in the tropical tropopause layer: implications for stratospheric injection, Atmos. Chem. Phys., 14, 13391-13410, doi:10.5194/acp-1413391-2014, 2014

Fitzenberger, R., Bösch, H., Camy-Peyret, C., Chipperfield, M. P., Harder, H., Platt, U., Sinnhuber, B.-M., Wagner, T., and Pfeilsticker, K.: First profile measurements of tropospheric BrO, Geophys. Res. Lett., 27, 2921-2924, doi:10.1029/2000GL011531, 2000.

Garcia, R. R., Marsh, D. R., Kinnison, D. E., Boville, B. A., and Sassi, F.: Simulation of secular trends in the middle atmosphere, 1950-2003, J. Geophys. Res.-Atmos., 112, D09301, doi:10.1029/2006JD007485, 2007.

Gomez Martin, J. C., Mahajan, A. S., Hay, T. D., Prados-Roman, C., Ordonez, C., MacDonald, S. M., Plane, J. M. C., Sorribas, M., Gil, M., Mora, J. F. P., Reyes, M. V. A., Oram, D. E., Leedham, E., and Saiz-Lopez, A.: Iodine chemistry in the eastern Pacific marine boundary layer, J. Geophys. Res.-Atmos., 118, 887-904, doi:10.1002/jgrd.50132, 2013.

Goodsite, M. E., Plane, J. M. C., and Skov, H.: A theoretical study of the oxidation of $\mathrm{Hg}^{0}$ to $\mathrm{HgBr}_{2}$ in the troposphere, Environ. Sci. Technol., 38, 1772-1776, doi:10.1021/es034680s, 2004.
Goodsite, M. E., Plane, J. M. C., and Skov, H.: Correction to A Theoretical Study of the Oxidation of $\mathrm{Hg}_{0}$ to $\mathrm{HgBr}_{2}$ in the Troposphere, Environ. Sci. Technol., 46, 5262-5262, doi:10.1021/es301201c, 2012.

Guentzel, J., Landing, W., Gill, G., and Pollman, C.: Processes influencing rainfall deposition of mercury in Florida, Environ. Sci Technol., 35, 863-873, doi:10.1021/es.001523+, 2001.

Gustin, M. S., Biester, H., and Kim, C. S.: Investigation of the light-enhanced emission of mercury from naturally enriched substrates, Atmos. Environ., 36, 3241-3254, doi:10.1016/S13522310(02)00329-1, 2002.

Gustin, M. S., Weiss-Penzias, P. S., and Peterson, C.: Investigating sources of gaseous oxidized mercury in dry deposition at three sites across Florida, USA, Atmos. Chem. Phys., 12, 9201-9219, doi:10.5194/acp-12-9201-2012, 2012.

Hall, B.: The Gas-Phase Oxidation of Elemental Mercury by Ozone, Water Air Soil Poll., 80, 301-315, doi:10.1007/BF01189680, 1995.

Hendrick, F., Van Roozendael, M., Chipperfield, M. P., Dorf, M., Goutail, F., Yang, X., Fayt, C., Hermans, C., Pfeilsticker, K., Pommereau, J.-P., Pyle, J. A., Theys, N., and De Mazière, M.: Retrieval of stratospheric and tropospheric BrO profiles and columns using ground-based zenith-sky DOAS observations at Harestua, $60^{\circ} \mathrm{N}$, Atmos. Chem. Phys., 7, 4869-4885, doi:10.5194/acp-7-4869-2007, 2007.

Holmes, C. D., Jacob, D. J., Mason, R. P., and Jaffe, D. A.: Sources and deposition of reactive gaseous mercury in the marine atmosphere, Atmos. Environ., 43, 2278-2285, doi:10.1016/j.atmosenv.2009.01.051, 2009.

Holmes, C. D., Jacob, D. J., Corbitt, E. S., Mao, J., Yang, X., Talbot, R., and Slemr, F.: Global atmospheric model for mercury including oxidation by bromine atoms, Atmos. Chem. Phys., 10, 12037-12057, doi:10.5194/acp-10-12037-2010, 2010.

Hynes, A., Donohoue, D., Goodsite, M., and Hedgecock, I.: Our current understanding of major chemical and physical processes affecting mercury dynamics in the atmosphere and at the airwater/terrestrial interfaces, in: Mercury Fate and Transport in the Global Atmosphere, edited by: Mason, R. and Pirrone, N., Springer, USA, 427-457, 2009

Kraus, S,: DOASIS - A Framework Design for DOAS, Shaker Verlag, University of Heidelberg, Heidelberg, Germany, 2006.

Landing, W. M., Caffrey, J. M., Nolek, S. D., Gosnell, K. J., and Parker, W. C.: Atmospheric wet deposition of mercury and other trace elements in Pensacola, Florida, Atmos. Chem. Phys., 10, 4867-4877, doi:10.5194/acp-10-4867-2010, 2010.

Landis, M. S., Ryan, J. V., ter Schure, A. F. H., and Laudal, D.: Behavior of Mercury Emissions from a Commercial Coal-Fired Power Plant: The Relationship between Stack Speciation and Near-Field Plume Measurements, Environ. Sci. Technol., 48, 13540-13548, doi:10.1021/es500783t, 2014.

Liang, Q., Stolarski, R. S., Kawa, S. R., Nielsen, J. E., Douglass, A. R., Rodriguez, J. M., Blake, D. R., Atlas, E. L., and Ott, L. E.: Finding the missing stratospheric $\mathrm{Br}_{\mathrm{y}}$ : a global modeling study of $\mathrm{CHBr}_{3}$ and $\mathrm{CH}_{2} \mathrm{Br}_{2}$, Atmos. Chem. Phys., 10, 2269-2286, doi:10.5194/acp-10-2269-2010, 2010.

Liang, Q., Atlas, E., Blake, D., Dorf, M., Pfeilsticker, K., and Schauffler, S.: Convective transport of very short lived bromocarbons to the stratosphere, Atmos. Chem. Phys., 14, 5781-5792, doi:10.5194/acp-14-5781-2014, 2014. 
Lin, J.-T. and McElroy, M. B.: Impacts of boundary layer mixing on pollutant vertical profiles in the lower troposphere: Implications to satellite remote sensing, Atmos. Environ., 44, 17261739, doi:10.1016/j.atmosenv.2010.02.009, 2010.

Lindberg, S. and Stratton, W.: Atmospheric mercury speciation: Concentrations and behavior of reactive gaseous mercury in ambient air, Environ. Sci. Technol., 32, 49-57, doi:10.1021/es970546u, 1998.

Liu, G., Cai, Y., Kalla, P., Scheidt, D., Richards, J., Scinto, L. J., Gaiser, E., and Appleby, C.: Mercury mass budget estimates and cycling seasonality in the Florida everglades, Environ. Sci. Technol., 42, 1954-1960, doi:10.1021/es7022994, 2008.

Long, M. S., Keene, W. C., Easter, R. C., Sander, R., Liu, X., Kerkweg, A., and Erickson, D.: Sensitivity of tropospheric chemical composition to halogen-radical chemistry using a fully coupled size-resolved multiphase chemistry-global climate system: halogen distributions, aerosol composition, and sensitivity of climate-relevant gases, Atmos. Chem. Phys., 14, 3397-3425, doi:10.5194/acp-14-3397-2014, 2014.

Lyman, S. N. and Jaffe, D. A.: Formation and fate of oxidized mercury in the upper troposphere and lower stratosphere, Nat. Geosci., 5, 114-117, doi:10.1038/NGEO1353, 2012.

Lyman, S. N., Gustin, M. S., Prestbo, E. M., Kilner, P. I., Edgerton, E., and Hartsell, B.: Testing and Application of Surrogate Surfaces for Understanding Potential Gaseous Oxidized Mercury Dry Deposition, Environ. Sci. Technol., 43, 6235-6241, doi:10.1021/es901192e, 2009.

Marsh, D., Mills, M. J., Kinnison, D. E., Garcia, R. R., Lamarque, J.-F., and Calvo, N.: Climate Change from 1850-2005 simulated in CESM1 (WACCM), J. Climate, 26, 7372-7391, doi:10.1175/JCLI-D-12-00558.1, 2013.

McClure, C. D., Jaffe, D. A., and Edgerton, E. S.: Evaluation of the $\mathrm{KCl}$ denuder method for gaseous oxidized mercury using $\mathrm{HgBr}_{2}$ at an in-service AMNet site, Environ. Sci. Technol., 43, 1143711444, doi:10.1021/es502545k, 2014.

McGrath-Spangler, E. L. and Molod, A.: Comparison of GEOS5 AGCM planetary boundary layer depths computed with various definitions, Atmos. Chem. Phys., 14, 6717-6727, doi:10.5194/acp-14-6717-2014, 2014.

Meller, R. and Moortgat, G.: Temperature dependence of the absorption cross sections of formaldehyde between 223 and $323 \mathrm{~K}$ in the wavelength range $225-375 \mathrm{~nm}$, J. Geophys. Res.-Atmos., 105, 7089-7101, doi:10.1029/1999JD901074, 2000.

Nair, U. S., Wu, Y., Walters, J., Jansen, J., and Edgerton, E. S.: Diurnal and seasonal variation of mercury species at coastal-suburban, urban, and rural sites in the southeastern United States, Atmos. Environ., 47, 499-508, doi:10.1016/j.atmosenv.2011.09.056, 2012.

Nair, U. S., Wu, Y., Holmes, C. D., Ter Schure, A., Kallos, G., and Walters, J. T.: Cloud-resolving simulations of mercury scavenging and deposition in thunderstorms, Atmos. Chem. Phys., 13, 10143-10157, doi:10.5194/acp-13-10143-2013, 2013.

Parrella, J. P., Jacob, D. J., Liang, Q., Zhang, Y., Mickley, L. J., Miller, B., Evans, M. J., Yang, X., Pyle, J. A., Theys, N., and van Roozendael, M.: Tropospheric bromine chemistry: implications for present and pre-industrial ozone and mercury, Atmos. Chem. Phys., 12, 6723-6740, doi:10.5194/acp-12-6723-2012, 2012.

Pehkonen, S. O. and Lin, C. J.: Aqueous photochemistry of mercury with organic acids, J. Air Waste Manage., 48, 144-150, 1998.
Prados-Roman, C., Butz, A., Deutschmann, T., Dorf, M., Kritten, L., Minikin, A., Platt, U., Schlager, H., Sihler, H., Theys, N., van Roozendael, M., Wagner, T., and Pfeilsticker, K.: Airborne DOAS limb measurements of tropospheric trace gas profiles: case studies on the profile retrieval of $\mathrm{O}_{4}$ and $\mathrm{BrO}$, Atmos. Meas. Tech., 4, 1241-1260, doi:10.5194/amt-4-1241-2011, 2011.

Pundt, I., Pommereau, J.-P., Chipperfield, M. P., van Roozendael, M., and Goutail, F.: Climatology of the stratospheric $\mathrm{BrO}$ vertical distribution by balloon-borne UV-visible spectrometry, J. Geophys. Res.-Atmos., 107, ACH 23-1-ACH 23-14, doi:10.1029/2002JD002230, 2002.

Read, K. A., Mahajan, A. S., Carpenter, L. J., Evans, M. J., Faria, B. V. E., Heard, D. E., Hopkins, J. R., Lee, J. D., Moller, S. J., Lewis, A. C., Mendes, L., McQuaid, J. B., Oetjen, H., Saiz-Lopez, A., Pilling, M. J., and Plane, J. M. C.: Extensive halogen-mediated ozone destruction over the tropical Atlantic Ocean, Nature, 453, 1232-1235, doi:10.1038/nature07035, 2008.

Rienecker, M. M., Suarez, M. J., Gelaro, R., Todling, R., Bacmeister, J., Liu, E., Bosilovich, M. G., Schubert, S. D., Takacs, L., Kim, G.-K., Bloom, S., Chen, J., Collins, D., Conaty, A., da Silva, A., Gu, W., Joiner, J., Koster, R. D., Lucchesi, R., Molod, A., Owens, T., Pawson, S., Pegion, P., Redder, C. R., Reichle, R., Robertson, F. R., Ruddick, A. G., Sienkiewicz, M., and Woollen, J.: MERRA: NASA's Modern-Era Retrospective Analysis for Research and Applications, J. Climate, 24, 3624-3648, doi:10.1175/JCLI-D-11-00015.1, 2011.

Rodgers, C. D.: Inverse Methods for Atmospheric Sounding: Theory and Practice, World Scientific, Singapore, 2000.

Rothman, L. S., Jacquemart, D., Barbe, A., Benner, D. C., Birk, M., Brown, L. R., Carleer, M. R., Chackerian, C., Chance, K., Coudert, L. H., Dana, V., Devi, V. M., Flaud, J.-M., Gamache, R. R., Goldman, A., Hartmann, J.-M., Jucks, K. W., Maki, A. G., Mandin, J.-Y., Massie, S. T., Orphal, J., Perrin, A., Rinsland, C. P., Smith, M. A. H., Tennyson, J., Tolchenov, R. N., Toth, R. A., Vander Auwera, J., Varanasi, P., and Wagner, G.: The HITRAN 2004 molecular spectroscopic database, J. Quant. Spectrosc. Ra., 96, 139-204, doi:10.1016/j.jqsrt.2004.10.008, 2005.

Rutter, A. P. and Schauer, J. J.: The effect of temperature on the gas-particle partitioning of reactive mercury in atmospheric aerosols, Atmos. Environ., 41, 8647-8657, doi:10.1016/j.atmosenv.2007.07.024, 2007.

Saiz-Lopez, A., Lamarque, J. F., Kinnison, D. E., Tilmes, S., Ordonez, C., Orlando, J. J., Conley, A. J., Plane, J. M. C., Mahajan, A. S., Santos, G. S., Atlas, E. L., Blake, D. ., Sander, S. P., Schauffler, S., Thompson, A. M., and Brasseur, G.: Estimating the climate significance of halogen-driven ozone loss in the tropical marine troposphere, Atmos. Chem. Phys., 12, 3939-3949, doi:10.5194/acp-12-3939-2012, 2012.

Saiz-Lopez, A., Baidar, S., Cuevas, C. A., Koenig, T. K., Fernandez, R. P., Dix, B., Kinnison, D. E., Lamarque, J.-F., RodriguezLloveras, X., Campos, T. L., and Volkamer, R.: Injection of iodine to the stratosphere, Geophys. Res. Lett., 42, 6852-6859, doi:10.1002/2015GL064796, 2015.

Salawitch, R., Weisenstein, D., Kovalenko, L., Sioris, C., Wennberg, P., Chance, K., Ko, M., and McLinden, C.: Sensitivity of ozone to bromine in the lower stratosphere, Geophys. Res. Lett., 32, L05811, doi:10.1029/2004GL021504, 2005.

Sander, R., Keene, W. C., Pszenny, A. A. P., Arimoto, R., Ayers, G. P., Baboukas, E., Cainey, J. M., Crutzen, P. J., Duce, R. A., 
Hönninger, G., Huebert, B. J., Maenhaut, W., Mihalopoulos, N., Turekian, V. C., and Van Dingenen, R.: Inorganic bromine in the marine boundary layer: a critical review, Atmos. Chem. Phys., 3, 1301-1336, doi:10.5194/acp-3-1301-2003, 2003.

Schmidt, J. A., Jacob, D. J., Horowitz, H. M., Hu, L., Sherwen, T., Evans, M. J., Liang, Q., Suleiman, R. M., Oram, D. E., Le Breton, M., Percival, C. J., Wang, S., Dix, B., and Volkamer, R.: Modeling the observed tropospheric $\mathrm{BrO}$ background: Importance of multiphase chemistry and implications for ozone, $\mathrm{OH}$, and mercury, J. Geophys. Res.-Atmos., in press, 2016.

Schofield, R., Johnston, P. V., Thomas, A., Kreher, K., Connor, B. J., Wood, S., Shooter, D., Chipperfield, M. P., Richter, A., von Glasow, R., and Rodgers, C. D.: Tropospheric and stratospheric BrO columns over Arrival Heights, Antarctica, 2002, J. Geophys. Res.-Atmos., 111, D22310, doi:10.1029/2005JD007022, 2006.

Schroeder, W. and Munthe, J.: Atmospheric mercury - An overview, Atmos. Environ., 32, 809-822, doi:10.1016/S13522310(97)00293-8, 1998.

Selin, N. E., Jacob, D. J., Park, R. J., Yantosca, R. M., Strode, S., Jaegle, L., and Jaffe, D.: Chemical cycling and deposition of atmospheric mercury: Global constraints from observations, J. Geophys. Res., 112, D02308, doi:10.1029/2006JD007450, 2007.

Selin, N. E., Jacob, D. J., Yantosca, R. M., Strode, S., Jaeglé, L., and Sunderland, E. M.: Global 3-D land-ocean-atmosphere model for mercury: Present-day versus preindustrial cycles and anthropogenic enrichment factors for deposition, Global Biogeochem. Cy., 22, GB2011, doi:10.1029/2007GB003040, 2008.

Selin, N. E., Sunderland, E. M., and Knightes, C. D.: Sources of Mercury Exposure for U.S. Seafood Consumers: Implications for Policy, Environ. Health Perspect., 118, 137-143, doi:10.1289/ehp.0900811, 2010.

Shah, V., Jaeglé, L., Gratz, L. E., Ambrose, J. L., Jaffe, D. A., Selin, N. E., Song, S., Campos, T. L., Flocke, F. M., Reeves, M., Stechman, D., Stell, M., Festa, J., Stutz, J., Weinheimer, A. J., Knapp, D. J., Montzka, D. D., Tyndall, G. S., Apel, E. C., Hornbrook, R. S., Hills, A. J., Riemer, D. D., Blake, N. J., Cantrell, C. A., and Mauldin III, R. L.: Origin of oxidized mercury in the summertime free troposphere over the southeastern US, Atmos. Chem. Phys., 16, 1511-1530, doi:10.5194/acp-16-1511-2016, 2016.

Sihler, H., Platt, U., Beirle, S., Marbach, T., Kühl, S., Dörner, S., Verschaeve, J., Frieß, U., Pöhler, D., Vogel, L., Sander, R., and Wagner, T.: Tropospheric BrO column densities in the Arctic derived from satellite: retrieval and comparison to ground-based measurements, Atmos. Meas. Tech., 5, 27792807, doi:10.5194/amt-5-2779-2012, 2012.

Soerensen, A. L., Sunderland, E. M., Holmes, C. D., Jacob, D. J., Yantosca, R. M., Skov, H., Christensen, J. H., Strode, S. A., and Mason, R. P.: An Improved Global Model for Air-Sea Exchange of Mercury: High Concentrations over the North Atlantic, Environ. Sci. Technol., 44, 8574-8580, doi:10.1021/es102032g, 2010.

Spietz, P., Martin, J. C. G., and Burrows, J. P.: Spectroscopic studies of the $\mathrm{I}_{2} / \mathrm{O}_{3}$ photochemistry - Part 2. Improved spectra of iodine oxides and analysis of the IO absorption spectrum, J. Photoch. Photobio. A, 176, 50-67, doi:10.1016/j.jphotochem.2005.08.023, 2005.

Streets, D., Zhang, Q., and Wu, Y.: Projections of global mercury emissions in 2050, Environ. Sci. Technol., 43, 2983-2988, doi:10.1021/es802474j, 2009.
Swartzendruber, P. C., Jaffe, D. A., Prestbo, E. M., Weiss-Penzias, P., Selin, N. E., Park, R., Jacob, D. J., Strode, S., and Jaeglé, L.: Observations of reactive gaseous mercury in the free troposphere at the Mount Bachelor Observatory, J. Geophys. Res., 111, D24301, doi:10.1029/2006JD007415, 2006.

Swartzendruber, P. C., Jaffe, D. A., and Finley, B.: Development and first results of an aircraft-based, high time resolution technique for gaseous elemental and reactive (oxidized) gaseous mercury, Environ. Sci. Technol., 43, 7484-7489, 2009.

Thalman, R. and Volkamer, R.: Temperature dependent absorption cross-sections of $\mathrm{O}_{2}-\mathrm{O}_{2}$ collision pairs between 340 and $630 \mathrm{~nm}$ and at atmospherically relevant pressure, Phys. Chem. Chem. Phys., 15, 15371-15381, doi:10.1039/c3cp50968k, 2013.

Theys, N., Van Roozendael, M., Hendrick, F., Fayt, C., Hermans, C., Baray, J.-L., Goutail, F., Pommereau, J.-P., and De Mazière, M.: Retrieval of stratospheric and tropospheric BrO columns from multi-axis DOAS measurements at Reunion Island $\left(21^{\circ} \mathrm{S}\right.$, $56^{\circ}$ E), Atmos. Chem. Phys., 7, 4733-4749, doi:10.5194/acp-74733-2007, 2007.

Theys, N., van Roozendael, M., Hendrick, F., Yang, X., De Smedt, I., Richter, A., Begoin, M., Errera, Q., Johnston, P. V., Kreher, K., and De Maziere, M.: Global observations of tropospheric BrO columns using GOME-2 satellite data, Atmos. Chem. Phys., 11, 1791-1811, doi:10.5194/acp-11-1791-2011, 2011.

Tong, Y., Eichhorst, T., Olson, M. R., McGinnis, J. E., Turner, I., Rutter, A. P., Shafer, M. M., Wang, X., and Schauer, J. J.: Atmospheric photolytic reduction of $\mathrm{Hg}$ (II) in dry aerosols, Environ. Sci. Process. Impacts, 15, 1883-1888, doi:10.1039/c3em00249g, 2013.

Tossell, J. A.: Calculation of the energetics for oxidation of gasphase elemental $\mathrm{Hg}$ by $\mathrm{Br}$ and $\mathrm{BrO}$, J. Phys. Chem. A, 107, 7804-7808, doi:10.1021/jp030390m, 2003.

Vandaele, A. C., Hermans, C., Simon, P. C., Carleer, M., Colin, R., Fally, S., Mérienne, M. F., Jenouvrier, A., and Coquart, B.: Measurements of the $\mathrm{NO}_{2}$ absorption crosssection from $42000 \mathrm{~cm}^{-1}$ to $10000 \mathrm{~cm}^{-1}(238-1000 \mathrm{~nm})$ at $220 \mathrm{~K}$ and $294 \mathrm{~K}$, J. Quant. Spectrosc. Ra., 59, 171-184, doi:10.1016/S0022-4073(97)00168-4, 1998.

Van Roozendael, M., Wagner, T., Richter, A., Pundt, I., Arlander, D., Burrows, J., Chipperfield, M., Fayt, C., Johnston, P., Lambert, J., Kreher, K., Pfeilsticker, K., Platt, U., Pommereau, J., Sinnhuber, B., Tornkvist, K., and Wittrock, F.: Intercomparison of BrO measurements from ERS-2 GOME, ground-based and balloon platforms, Remote Sensing of Trace Constituents in the Lower Stratosphere, Troposphere and the Earth's Surface: Global Observations, Air Pollution and the Atmospheric Correction, Adv. Space Res., 29, 1661-1666, doi:10.1016/S0273-1177(02)000984, 2002.

Volkamer, R., Spietz, P., Burrows, J., and Platt, U.: Highresolution absorption cross-section of glyoxal in the UV-vis and IR spectral ranges, J. Photoch. Photobio. A, 172, 35-46, doi:10.1016/j.jphotochem.2004.11.011, 2005.

Volkamer, R., Baidar, S., Campos, T. L., Coburn, S., DiGangi, J. P., Dix, B., Eloranta, E., Koenig, T. K., Morley, B., Ortega, I., Pierce, B. R., Reeves, M., Sinreich, R., Wang, S., Zondlo, M. A., and Romashkin, P. A.: Aircraft measurements of BrO, IO, glyoxal, $\mathrm{NO}_{2}, \mathrm{H}_{2} \mathrm{O}, \mathrm{O}_{2}-\mathrm{O}_{2}$ and aerosol extinction profiles in the tropics: Comparison with aircraft-/ship-based in situ and lidar measure- 
ments, Atmos. Meas. Tech. 8, 2121-2148, doi:10.5194/amt-82121-2015, 2015.

Wang, S., Schmidt, J. A., Baidar, S., Coburn, S., Dix, B., Koenig, T., Apel, E. C., Bowdalo, D., Campos, T. L., Eloranta, E., Evans, M. J., diGangi, J. P., Zondlo, M. A., Gao, R. S., Haggerty, J. A., Hall, S. R., Hornbrook, R. S., Jacob, D. J., Morley, B., Pierce, B. R., Reeves, M., Romashkin, P. A., ter Schure, A., and Volkamer, R.: Active and widespread halogen chemistry in the tropical and subtropical free troposphere, P. Natl. Acad. Sci. USA, 112, 92819286, doi:10.1073/pnas.1505142112, 2015.

Weiss-Penzias, P., Amos, H. M., Selin, N. E., Gustin, M. S., Jaffe, D. A., Obrist, D., Sheu, G.-R., and Giang, A.: Use of a global model to understand speciated atmospheric mercury observations at five high-elevation sites, Atmos. Chem. Phys., 15, 11611173, doi:10.5194/acp-15-1161-2015, 2015.

Weiss-Penzias, P. S., Gustin, M. S., and Lyman, S. N.: Source of gaseous oxidized mercury and mercury dry deposition at two southeastern U.S. sites, Atmos. Environ., 45, 4569-4579, doi:10.1016/j.atmosenv.2011.05.069, 2011.
Wilmouth, D., Hanisco, T., Donahue, N., and Anderson, J.: Fourier transform ultraviolet spectroscopy of the $A_{2} \Pi 3 / 2<-X_{2} \Pi 3 / 2$ transition of BrO, J. Phys. Chem. A, 103, 8935-8945, doi:10.1021/jp991651o, 1999.

Yang, X., Cox, R. A., Warwick, N. J., Pyle, J. A., Carver, G. D., O'Connor, F. M., and Savage, N. H.: Tropospheric bromine chemistry and its impacts on ozone: A model study, J. Geophys. Res.-Atmos., 110, D23311, doi:10.1029/2005JD006244, 2005.

Zhang, Y., Jaeglé, L., van Donkelaar, A., Martin, R. V., Holmes, C. D., Amos, H. M., Wang, Q., Talbot, R., Artz, R., Brooks, S., Luke, W., Holsen, T. M., Felton, D., Miller, E. K., Perry, K. D., Schmeltz, D., Steffen, A., Tordon, R., Weiss-Penzias, P., and Zsolway, R.: Nested-grid simulation of mercury over North America, Atmos. Chem. Phys., 12, 6095-6111, doi:10.5194/acp12-6095-2012, 2012. 